\title{
COST OF EQUITY CAPITAL AND UNDERSTATED PENSION LIABILITIES 1
}

\section{Huan Yang', Jun Cai'2, Lin Huang', and Robert I. Webb ${ }^{3 *}$}

1. Southwestern University of Finance and Economics

2. City University of Hong Kong

3. University of Virginia

* Corresponding Author: Robert I. Webb, McIntire School of Commerce, University of Virginia, Charlottesville, VA, USA, $\bowtie$ Email: riw4j@virginia.edu

\begin{abstract}
Pension discount rates have a powerful effect on the size of reported defined benefit corporate pension liabilities because of the long-term nature of projected benefit obligations. Firms often choose pension discount rates that are above the guideline long-term Treasury, AAA-grade, and AA-grade corporate bond yields. We assess the sizes of understated pension liabilities relative to these benchmark interest rates and relate them to individual firms' implied cost of equity. We find that firms with large, understated pension liabilities have a higher implied cost of equity after taking into account standard control variables and other pension information such as funded status and mandatory contributions.
\end{abstract}

Keywords: Cost of equity, pension discount rates, understated pension liabilities

\section{Introduction}

The cost of equity is one of the most important factors firms consider when making investment and financing decisions. A number of papers study alternative measures of cost of equity and relate them to beta, idiosyncratic volatility, size, book-to-market ratio, leverage, and growth expectations (see Botosan and Plumlee [2005]; Francis et al., [2004, 2005]), among many other variables.2, 3 One common feature of these early studies is that they are based on either stock market information or reported financial statements or a combination of the two. In this paper, we examine the role of pension information. Unlike earnings-based information, pension information is primarily disclosed in notes to the financial statements rather than recognized in the financial statements themselves. Pension accounting also involves a complex smoothing procedure and the rules governing pension accounting keep changing over time. Even for sophisticated investors and analysts, the implication of pension information on firm valuation is difficult to process (Picconi [2006]).

We consider three measures of pension information: funded status, mandatory contributions, and understated pension liabilities. Understated pension liabilities capture the difference between reported pension liabilities and liabilities discounted at alternative guideline interest rates set forth by pension governing bodies and financial reporting standards. While the effect of funded status and mandatory contributions on cost of equity has been analysed by Campbell, Dhaliwal, and Schwartz,

\footnotetext{
' City University of Hong Kong Strategic Grant (SRG 7008142) is gratefully acknowledged. All errors remain our own responsibility.

2 See Bhattacharya, Daouk, and Welker [2003]; Botosan, Plumlee, and Xie [2004]; Ecker, Francis, Kim, Olsson, and Schipper [2006]; Verdi [2006]; Nichols [2006]; Core, Guay, and Verdi [2008]; Liu and Wysocki [2008]; Mclnnis (2010); and Ogneva [2012].

3 Diamond and Verrecchia [1991], O'Hara [2003], Easley and O'Hara [2004], and Lambert, Leuz, and Verrecchia [2007] develop alternative models to examine the role of structure, quality, and disclosure of information affecting firms' cost of equity.
} 
Jr. [2012], the effect of understated pension liabilities on the cost of equity has not yet been explored in the literature.

We choose to focus on understated pension liabilities because (i) pension obligations such as projected benefit obligations are large in magnitude and very sensitive to small changes in pension discount rates because, as with any long-term fixed income instrument, these future cash flows are long term in nature. A rule of thumb is that a $1 \%$ change in the discount rate will lead to a $10 \%$ to $15 \%$ change in the present values of future cash flows. (ii) There are benefits and costs associated with choosing a high or low pension discount rate (Feldstein and Morck, [1983]. (iii) It has been well established that defined benefit pension accounting allows for considerable managerial discretion (Bergstresser, Desai, and Rauh [2006]. Managers may use pension accounting to boost reported earnings if investors do not "pierce the veil" (Coronado and Sharpe, [2003].

The legislation governing the minimum funding requirement for defined benefit corporate pension plans is the Employee Retirement Income Security Act (ERISA) enacted in 1974. It specifies that the interest rate used to calculate the present value of a plan's liabilities "must be within a specified range above or below the weighted average of the interest rates on 30-year Treasury bonds for the previous four-year period." That range is normally $90 \%$ to $105 \%$ of the weighted average. For financial reporting purposes in calculating projected and accumulated benefit obligations, the Financial Accounting Standard Board (FASB) statement SFAS 87 suggests "employers may also look to rates of return on high-quality fixed-income investments."

In this paper, we aim to answer two questions. First, to what extent do firms choose their pension discount rates in order to understate their true pension liabilities? Second, do understated pension liabilities affect firms' cost of capital? By choosing a high pension discount rate, firms can hide some of their pension obligations. The issue is whether investors see through the hidden pension liabilities and adjust their valuation of the firm's stock and cost of equity.

Our paper is related to a few other studies (Black [1989]; Brown and Wilcox [2009]; Novy-Marx and Rauh [2009]; Lucas and Zeldes [2006 and 2009]; Andonov, Baver, and Cremers [2013]). Novy-Marx and Rauh [2011] evaluate the economic magnitude of public state pension liabilities. Hann, Lu, and Subramanyam [2007] develop methods to obtain defined benefit pension parameters. Building on their methods, we replace firm specific pension discount rates with alternative interest rate benchmarks to measure understated pension liabilities.

We examine the implied cost of equity rather than realized future returns, as suggested by Elton [1999] and Leuz and Wysocki [2008]. Therefore, our work differs from the two studies (Franzoni and Marin [2006]; Picconi, [2006] that use realized returns.

Our major findings can be summarized as follows. First, for each of the 11,450 firm-year observations of pension discount rates, we find the corresponding benchmark interest rates from 30-year Treasury bonds, 20-year, and 25-year AAA-grade corporate bonds. We also construct a term-structure benchmark AAA-grade corporate bond yield to take into account duration difference in pension liabilities. The average pension discount rate is $6.43 \%$, which is $1.01 \%, 0.80 \%, 0.83 \%$, and $0.70 \%$ higher than these four benchmark yields, respectively. The majority, or $86.9 \%, 83.9 \%, 84.3 \%$, and $80.8 \%$, of the 11,450 firm-year observations are associated with pension discount rates higher than these four benchmark yields. Using the 30-year Treasury bond yield, and the aforementioned three AAA-grade corporate bond yields, the average projected benefit obligations (PBOs) are understated by \$141 million, $\$ 121$ million, $\$ 122$ million, and $\$ 121$ million, respectively. This is equivalent to $2.7 \%, 2.3 \%, 2.3 \%$, and $2.3 \%$ of the fiscal-year-end market value, respectively. The average accumulated benefit obligations (ABOs) are understated by \$125 million, \$107 million, \$107 million, and \$108 million, equivalent to $2.4 \%, 2.0 \%, 2.1 \%$, and $2.1 \%$ of the fiscal-year-end market value, respectively. Relative to AA-grade corporate bond yields, the average difference between firm pension discount rates and benchmark yields becomes much smaller, and the percentage of firm pension discount rates higher than benchmark yields is also much lower. As a result, understated pension liabilities also become much smaller. 
Second, we find that there is a reliable negative relation between understated pension liabilities and cost of equity after controlling for firm characteristics. Since understated pension liabilities are measured in negative numbers, the negative regression coefficients imply that firms with large amounts of hidden pension obligations face high costs of equity. The estimated coefficients (tstatistic) on understated PBOs are $-0.029(-3.11),-0.032(-2.91),-0.031$ (-2.99), and -0.027 (-2.81), respectively, relative to 30-year Treasury bond, 20-year, 25-year, and term structure AAA-grade corporate bond yields. The association between the cost of equity and understated $A B O$ s is even stronger. The estimated coefficients are $-0.035(-3.26),-0.038(-3.05),-0.037(-3.12)$, and $-0.033(-2.97)$, respectively.

Third, we address the endogeneity issue with respect to the significant negative relation between the cost of equity and understated pension liabilities documented thus far. The endogeneity issue exists because pension discount rates are decision variables individual firms can choose. We rely on twostage (2SLS) and three-stage least squares (3SLS) instrumental variable analysis. We conclude that the causal direction is from understated pension liabilities to the cost of equity.

The rest of the paper proceeds in the following way. Section 2 describes the data sources and sample screening. Section 3 describes the models for deriving the implied cost of equity. Section 4 explains the control variables. Section 5 provides summary statistics. Section 6 examines pension discount rates in relation to interest rate benchmarks. Section 7 assesses the magnitude of understated PBOs and $A B O$ s. Section 8 studies the impact of understated pension liabilities on the implied cost of equity. Section 9 investigates the endogeneity issue. Finally, Section 10 concludes the paper.

\section{Data Sources, Sample Screening, and FASB Statements}

\subsection{Data Sources}

The data for U.S. equity markets is from WRDS's CRSP and COMPUSTAT merge files. We obtain market capitalization, daily individual stock returns, and value-weighted market portfolio returns from CRSP. The annual accounting items and pension variables are from COMPUSTAT. One-yearahead and two-years-ahead forecasts of earnings per share, long-term earnings growth rate forecasts, and shares outstanding are from IBES. The data for 30-year Treasury bond yields are from WRDS. The yields on AAA-grade and AA-grade corporate bond yields are from Barclays Bank PLC. We obtain 15, 20, 25, and 30-year yields and number of bonds used to calculate the yields for AAAgrade and AA-grade corporate bonds. ${ }^{4}$

\subsection{Sample Construction}

Our sample firms consist of all NYSE/AMEX/NASDAQ firms that appear in the CRSP/COMPUSAT files. We include all industrial firms but exclude financial firms with 4-digit SIC codes between 6000 and 6999. Furthermore, we require firms to have a one-year-ahead and a two-years-ahead earnings-pershare (EPS) forecast, actual earnings-per-share, and shares outstanding from IBES. The merged CRSP/COMPUSTAT/IBES files generate a total of 41,653 firm-year observations from 6,147 firms during our sample period from October 1988 to June 2013. The pension dataset from COMPUSTAT contains 21,422 firm-year observations with non-missing PAs and PBOs on 1,556 firms over the same period. ${ }^{5}$ After merging these two datasets, we retain 13,089 firm-year observations. We further require estimated cost of equity be available for the four models we consider. This eliminates an additional

\footnotetext{
${ }_{4}^{4}$ During our sample period from 1988 to 2012, the average number of bonds constituting 15, 20, 25, and 30-year AAA-grade corporate bond yields are 60,45,47, and 15. The average number of bonds that constitute 15, 20, 25, and 30-year AA-grade corporate bond yields are 48,39,64, and 29. For shorter maturity AAA-grade and AA-grade bond yields, the number of bonds is much larger.

5 The firm-year observations and number of firms with pension information are similar to those reported in Rauh [2006] and Picconi [2006].
} 
700 firm-year observations. Finally, we delete 939 firm-year observations with missing explanatory variables. Our final sample consists of 11,450 firm-year observations from 1,217 firms.

\section{Cost of Equity}

\subsection{Existing Models of the Cost of Equity}

We employ the following four models from the literature to obtain estimates for implied cost of equity: Gebhardt, Lee, and Swaminathan [2001]; Claus and Thomas [2001]; Ohlson and Juettner-Nauroth [2005]; and Easton [2004]. All four models are consistent with Gordon's [1962] dividend growth model, with some important differences. The Gebhardt, Lee, and Swaminathan [2001] and Claus and Thomas [2001] models are special cases of the residual income model in which dividend payments each period are modeled as:

$$
P_{t}=B E_{t}+\sum_{\tau=1}^{T} \frac{\left(F E P S_{t+\tau}-x \cdot B E_{t+\tau-1}\right)}{(1+x)^{\tau}}+T V_{T}
$$

where $x$ denotes cost of equity, $P_{t}$ is stock price per share, $B E_{t}$ is expected book value of equity per share, and $F E P S_{t+\tau}$ is expected earnings per share. The main difference between the Gebhardt, Lee, and Swaminathan [2001] and Claus and Thomas [2001] models lies in the assumptions made in computing terminal value $T V_{T}$.

Easton [2004] and Ohlson and Juettner-Nauroth [2005] develop an alternative representation of the dividend growth model, or abnormal earnings growth model, as follows:

$$
P_{t}=\frac{F E P S_{t}}{x}+\sum_{\tau=1}^{\infty} \frac{A G R_{t+\tau}}{x \cdot(1+x)^{\tau}},
$$

where $A G R_{t+\tau}$ equals expected abnormal growth in earnings. The major difference between the Easton [2004] and Ohlson and Juettner-Nauroth [2005] models lies in the assumption regarding expected abnormal growth in earnings. The detailed formulae to obtain the implied cost of equity from these four models are provided in unreported Appendix I.

\section{Control Variables}

\subsection{Firm Characteristics}

We consider several firm specific characteristics in our cross-sectional analysis, including beta (BETA), time-trend adjusted residual standard deviation (ASTD), market value (ME), book-to-market ratio $(B M)$, market leverage (MLEV), liquidity (LIQ), interest coverage (INTCOV), operating margin (MARGIN), earnings loss frequency (LOSS), transparency (TRANS), Ohlson's [1980] bankruptcy score (OBS), and long-term growth rate of earnings per share (LGROW). The details of market and accounting items used to construct the variables are in unreported Appendix I. 


\subsection{Industry Cost of Equity}

The industry cost of equity IND_COST has an important effect on individual firms' cost of equity (Gebhardt, Lee, and Swaminathan [2001]; Gode and Mohanram [2003]). For each of the 11,450 firmyear observations in our final sample, we obtain the corresponding industry median cost of equity. The industry median is taken from all firms with pension data in the same industry as the sample firm. The forty-eight industry classification is based on Fama and French [1997].

\subsection{Pension Variables}

Pension plan related variables include plan assets (PA), projected benefit obligations (PBO), accumulated benefit obligations ( $A B O)$, funded status (FS), and Moody's measure of mandatory contributions $(M C)$. The details of the construction of these variables using COMPUSTAT items are available upon request.

The two primary variables used to measure the financial health of pension plans are funded status and mandatory contributions. Funded status (FS) is the difference between plan assets (PA) and projected benefit obligations (PBO). Rauh [2006] computes mandatory funding requirements for individual pension plans within each firm based on IRS 5500 filings to the U.S. Labor Department. IRS 5500 forms usually release data with a significant lag.

Alternatively, Mathur, Jonas, and LaMonte [2006] and Campbell, Dhaliwal, and Schwartz Jr. [2012] use a simpler measure for mandatory pension contributions. Their method for determining mandatory pension contributions relies on publicly available accounting disclosures in 10-K reports. Specifically,

$$
\begin{aligned}
M C_{i, t}= & -\left(S C_{i, t}+\left(A B O_{i, t}-P A_{i, t}\right) / 30\right), & & \text { if } P B O_{i, t} \geq P A_{i, t}, \\
& =0, & & \text { if } P B O_{i, t}<P A_{i, t},
\end{aligned}
$$

where the funding shortfall of ABO-PA is amortized over a 30-year period before 2006.

\section{Summary Statistics}

Table 1 provides summary statistics. We use COST_GLS, COST_CT, COST_PE, and COST_OJ to denote implied cost of equity obtained from the four models, respectively. COST is the simple average of the four individual measures of cost of equity. The simple average cost of equity COST has a mean of 10.23\%. Panel B computes the pairwise correlations between these four measures of cost of equity. All of them are positive and highly significant.

Panel A of Table 1 also summarizes firm characteristics including BETA, ASTD, ME, BM, MLEV, LIQ, INTCOV, MARGIN, LOSS, TRANS, OBS, and LGROW. All of these variables have been winsorized at $1 \%$ and $99 \%$. Panels $B$ and $C$ further report the correlations between these firm characteristics. Two pension variables FS and $M C$ are of primary interest. Panel $A$ shows that the average funded status is $-1.77 \%$ of fiscal-year-end market value. The average mandatory contribution is $-0.41 \%$ of fiscal-yearend market value. Panel C reports that the correlation between FS and MC is 0.70 . 
Table 1: Summary Statistics

\begin{tabular}{|c|c|c|c|c|c|c|}
\hline Panel A: Summary Statistics & & $25 \%$ & Median & Mean & $75 \%$ & $\begin{array}{l}\text { Std. } \\
\text { Dev. }\end{array}$ \\
\hline \multicolumn{7}{|l|}{ Cost of Equity } \\
\hline $\begin{array}{l}\text { Cost of Equity (\%), Mean of the Four Estimated } \\
\text { Cost of Equity }\end{array}$ & COST & 8.37 & 9.68 & 10.23 & 11.34 & 3.00 \\
\hline $\begin{array}{l}\text { Cost of Equity (\%), Gebhardt, Lee, and } \\
\text { Swaminathan [2001] }\end{array}$ & COST_GLS & 6.01 & 7.66 & 7.98 & 9.58 & 2.92 \\
\hline Cost of Equity (\%), Claus and Thomas [2001] & COST_CT & 7.76 & 9.01 & 9.68 & 10.50 & 4.25 \\
\hline $\begin{array}{l}\text { Cost of Equity (\%), Ohlson and Juettner-Nauroth } \\
\text { [2005] }\end{array}$ & COST_OJ & 9.47 & 10.95 & 11.53 & 12.90 & 3.19 \\
\hline Cost of Equity (\%), Easton [2004] & COST_PE & 9.12 & 10.79 & 11.74 & 13.35 & 4.16 \\
\hline \multicolumn{7}{|l|}{ Firm Characteristics } \\
\hline Beta & BETA & 0.54 & 0.87 & 0.92 & 1.26 & 0.54 \\
\hline $\begin{array}{l}\text { Time-Trend Adjusted Residual Standard } \\
\text { Deviation }\end{array}$ & ASTD & 0.62 & 0.81 & 0.89 & 1.06 & 0.36 \\
\hline Market Value at June (billion US\$) & $M E$ & 0.54 & 1.72 & 7.22 & 5.51 & 16.95 \\
\hline Book-†o-Market Ratio & $B M$ & 0.31 & 0.49 & 0.57 & 0.75 & 0.35 \\
\hline Market Leverage & MLEV & 0.08 & 0.22 & 0.35 & 0.47 & 0.42 \\
\hline Liquidity & $L I Q$ & 0.01 & 0.03 & 0.07 & 0.11 & 0.08 \\
\hline Interest Coverage & INTCOV & 3.00 & 5.58 & 15.16 & 12.83 & 24.97 \\
\hline Operating Margin & MARGIN & 0.10 & 0.15 & 0.18 & 0.22 & 0.10 \\
\hline $\begin{array}{l}\text { Percentage of Net Income Loss Years Over the } \\
\text { Past Three years }\end{array}$ & LOSS & 0.00 & 0.00 & 0.08 & 0.00 & 0.19 \\
\hline Transparency Measure & TRANS & -0.05 & -0.04 & -0.04 & -0.02 & 0.02 \\
\hline Ohlson's (1980) Bankruptcy Score & OBS & -2.41 & -1.56 & -1.61 & -0.78 & 1.20 \\
\hline Expected Long-Term Earnings Growth Rate & LGROW & 0.09 & 0.12 & 0.14 & 0.15 & 0.12 \\
\hline \multicolumn{7}{|l|}{ Industry Cost of Equity } \\
\hline $\begin{array}{l}\text { Mean of the Four Measures of Industry Cost of } \\
\text { Equity (\%) }\end{array}$ & IND_COST & 9.22 & 10.13 & 10.28 & 11.14 & 1.71 \\
\hline \multicolumn{7}{|l|}{ Pension Variables } \\
\hline Funded Status (\%) & FS & -3.61 & -0.95 & -1.77 & 0.37 & 7.63 \\
\hline Mandatory Contribution (\%) & $M C$ & -0.57 & -0.18 & -0.41 & 0.00 & 0.61 \\
\hline
\end{tabular}

\begin{tabular}{|c|c|c|c|c|}
\hline Panel B: Pairwise Correlations between Cost of Equity & COST_GLS & COST_CT & COST_OJ & $\begin{array}{c}\text { COST_P } \\
E\end{array}$ \\
\hline $\begin{array}{l}\text { COST } \\
\text { COST_GLS } \\
\text { COST_CT } \\
\text { COST_OJ }\end{array}$ & $0.65^{* *}$ & $\begin{array}{l}0.82^{* *} \\
0.37^{* *}\end{array}$ & $\begin{array}{l}0.92^{* *} \\
0.44^{* *} \\
0.68^{* *}\end{array}$ & $\begin{array}{l}0.89^{* *} \\
0.46^{* *} \\
0.55^{* *} \\
0.87^{* *}\end{array}$ \\
\hline
\end{tabular}

\begin{tabular}{|c|c|c|c|c|c|c|c|c|}
\hline \multicolumn{9}{|c|}{ Panel C: Pairwise Correlations between Cost of Equity, Firm Characteristics, and Pension Variables } \\
\hline & BETA & ASTD & ME & BM & MLEV & LIQ & INTCOV & MARGIN \\
\hline COST & $0.10^{* *}$ & $0.33^{* *}$ & $-0.18^{* *}$ & $0.44^{* *}$ & $0.31^{* *}$ & $0.23^{* *}$ & $-0.13^{* *}$ & $-0.28^{* *}$ \\
\hline BETA & & $0.35^{* *}$ & $-0.03^{* *}$ & $-0.10^{* *}$ & $-0.09 * *$ & $-0.34^{* *}$ & $0.08^{* *}$ & $-0.14^{* *}$ \\
\hline ATD & & & $-0.23^{* *}$ & $0.05^{* *}$ & $0.07^{* *}$ & $0.10^{* *}$ & $0.09^{* *}$ & $-0.27^{* *}$ \\
\hline ME & & & & $-0.21^{* *}$ & $-0.15^{* *}$ & $-0.23^{* *}$ & $0.06^{* *}$ & $0.24^{* *}$ \\
\hline BM & & & & & $0.58^{* *}$ & $0.20^{* *}$ & $-0.24^{* *}$ & $-0.06^{* *}$ \\
\hline MLEV & & & & & & $0.13^{* *}$ & $-0.36^{* *}$ & $0.02 *$ \\
\hline \multirow{3}{*}{$\begin{array}{l}\text { LIQ } \\
\text { INTCOV }\end{array}$} & & & & & & & $-0.07^{* *}$ & $-0.05^{* *}$ \\
\hline & & & & & & & & $0.09 * *$ \\
\hline & LOSS & TRANS & OBS & LGROW & \multicolumn{2}{|c|}{ IND_COST } & FS & MC \\
\hline COST & $0.24^{* *}$ & $-0.15^{* *}$ & $0.18^{* *}$ & $0.54^{* *}$ & \multicolumn{2}{|c|}{$0.57^{* *}$} & $-0.06^{* *}$ & $-0.18^{* *}$ \\
\hline LOSS & & $-0.19^{* *}$ & $0.18^{* *}$ & $0.22^{* *}$ & \multicolumn{2}{|c|}{$0.10^{* *}$} & $-0.18^{* *}$ & $-0.20^{* *}$ \\
\hline TRANS & & & $0.08^{* *}$ & $-0.20^{* *}$ & \multicolumn{2}{|c|}{$-0.10^{* *}$} & $0.02^{* *}$ & $-0.04^{* *}$ \\
\hline OBS & & & & $-0.02 * *$ & \multirow{2}{*}{\multicolumn{2}{|c|}{$\begin{array}{l}0.01 \\
0.26^{* *}\end{array}$}} & $-0.13^{* *}$ & $-0.26 * *$ \\
\hline LGROW & & & & & & & $-0.06^{* *}$ & $-0.04^{* *}$ \\
\hline IND_COST & & & & & & & $0.02^{*}$ & $-0.03^{* *}$ \\
\hline FS & & & & & & & & $0.70^{* *}$ \\
\hline
\end{tabular}

Note: The sample covers 11,450 firm-year observations from 1,217 firms from October 1988 to June 2013. Panel A of the table provides summary statistics for variables that belong to the following categories: individual firms' cost of equity, firm characteristics, industry cost of equity, and pension variables. COST is the simple average of four individual measures of cost of equity (COST_GLS, COST_CT, COST_OJ, and COST_PE). For each firm-year observation, individual measures of cost of equity are estimated based on each of the following four models: Gebhardt, Lee, and Swaminathan [2001]; Claus and Thomas [2001]; Ohlson and Juettner-Nauroth [2005]; and Easton [2004]. Firm characteristics include beta (BETA), time-trend adjusted residual standard deviations (ASTD), 
market value in June of each year (ME), book-to-market ratio (BM), market leverage (MLEV), liquidity (LIQ), interest coverage (INTCOV), operating margin (MARGIN), percentage of net income loss years over the past three years (LOSS), transparency measure (TRANS), Ohlson's (1980) bankruptcy score (OBS), and expected longterm earnings growth rate (LGROW). Industry cost of equity IND_COST is the simple average of the estimates from the four models (IND_COST_GLS, IND_COST_CT, IND_COST_OJ, and IND_COST_PE), where each estimate is the median value of individual firms' cost of equity from firms in the same industry during the fiscal year. The forty-eight industry classification is based on Fama and French [1997]. Pension variables include funded status (FS) and mandatory contributions (MC). Panels B and C report pairwise correlations. The definitions of the variables are provided in Appendix I. Market data including market value, daily stock returns, and valueweighted market returns are from CRSP. Accounting and pension data are from COMPUSTAT. Earnings forecast data are from I/B/E/S. ** indicates significance at the $5 \%$ level; * indicates significance at the $10 \%$ level.

\section{Pension Discount Rates and Interest Rate Benchmarks}

Table 2 compares the pension discount rates assumed by firms with alternative interest rate benchmarks. For each of the 11,450 firm-year observations of pension discount rates, we find the corresponding yields on 30-year Treasury bonds, 20-year and 25-year AAA-grade corporate bonds, and 20-year and 25-year AA-grade corporate bonds.

Table 2: Pension Discount Rate, Treasury Bond Yield, and High-Grade Corporate Bond Yield

\begin{tabular}{|c|c|c|}
\hline Panel A: Mean Percentage Difference in $r^{D I S C O U N T}$ - $r^{\text {Benchmark }}$ & Mean (\%) & Median (\%) \\
\hline rDISCOUNT $-r^{T B 30 Y}$ & 1.01 & 1.12 \\
\hline rDISCOUNT - rAAA2OY & 0.80 & 0.98 \\
\hline rDISCOUNT - rAAA25Y & 0.83 & 0.96 \\
\hline rDISCOUNT - rAAATM & 0.70 & 0.91 \\
\hline rDISCOUNT - rAA2OY & -0.34 & -0.08 \\
\hline rDISCOUNT - rAA25Y & -0.24 & 0.02 \\
\hline rDISCOUNT - rAATM & -0.26 & -0.01 \\
\hline Observations & 11,450 & 11,450 \\
\hline \multicolumn{3}{|c|}{ Panel B: Percentage of Firm-Year Observations with rDISCOUNT $>$ r Benchmark } \\
\hline $\begin{array}{ll}\text { rDISCOUNT }>\text { rTB30Y } & 86.9 \%\end{array}$ & & \\
\hline rDISCOUNT > & & \\
\hline rDISCOUNT > rAAA25Y & & \\
\hline rDISCOUNT > rAAATM & & \\
\hline rDISCOUNT > rAA2OY & & \\
\hline rDISCOUNT > rAA25Y & & \\
\hline rDISCOUNT > rAATM & & \\
\hline Observations & & \\
\hline
\end{tabular}

Note: The sample covers 11,450 firm-year observations from 1,217 firms from October 1988 to June 2013. Panel A summarizes the difference between the pension discount rate (rDISCOUNT) and the alternative interest rate benchmarks including 30 -year Treasury bond yields (r'B30Y), 20-year and 25-year AAA-grade corporate bond yields (rAAA20Y and rAAA25Y). 20-year and 25-year AA-grade corporate bond yields ( $r$ AA2OY and $r^{A A 25 Y}$ ) and term structure AAA-grade and AA-grade corporate bond yields ( $r$ AAATM and rAATM). For each firm-year observation with a pension discount rate, a corresponding yield r'B30Y, rAAA20Y, rAAA25Y, rAA20Y, rAA25Y is first matched. Then the mean and median statistics are calculated among all firm-year observations. Panel $B$ reports the percentage of firm-year observations for which the pension discount rate is higher than the corresponding interest rate benchmarks. ${ }^{* *}$ indicates significance at the $5 \%$ level; * indicates significance at the $10 \%$ level. Petersen (2009) one-dimension firm-clustered t-statistics are reported.

We construct term-structure AAA yields using the 15,20,25, and 30-year AAA yields based on our estimated value of number of years to retirement $N$. This procedure also applies to term-structure AA yields using the 15,20,25, and 30-year AA yields.

We calculate the average difference between pension discount rates and alternative interest rate benchmarks rDIsCOUNT $-r$ Benchmark in Panel A of Table 2. The first column shows that given the average pension discount rate from the 11,450 firm-year observations was $6.43 \%$, the average pension discount rate is $1.01 \%, 0.80 \%, 0.83 \%$, and $0.70 \%$ higher than the average 30 -year Treasury bond, 20 - 
year, 25-year, and term-structure AAA-grade corporate bond yields, respectively. The average difference becomes negative, or $-0.34 \%,-0.24 \%$, and $-0.26 \%$, respectively, relative to the 20 -year, 25 year, and term-structure AA-grade corporate bond yields.

Panel B of Table 2 also summarizes the percentage of firm-year observations with pension discount rates larger than the corresponding interest rate benchmark. For example, Column 2 reports that $86.9 \%$ of the 11,450 pension discount rates are larger than the corresponding 30-year Treasury bond yields, while $83.9 \%, 84.3 \%$, and $80.8 \%$ are larger than the 20 -year, 25 -year, and term-structure AAAgrade corporate bond yields, respectively. Therefore, the majority of the pension discount rates are above the long-term Treasury and AAA-grade corporate bond yields. In contrast, the percentages drop noticeably to $43.0 \%, 52.1 \%$, and $49.3 \%$ relative to the long-term AA-grade benchmark yields.

We illustrate the evolution of pension discount rates and corresponding interest rate benchmarks for each year from 1989 to 2013 in Figure 2. The gap between pension discount rates and 30-year Treasury bond yields is the largest, followed by the gap between pension discount rates and longterm AAA-grade corporate bond yields. The gap seems to have not only persisted but also widened over time. On the other hand, the gap between pension discount rates and AA-grade corporate bond yields is much smaller.

\section{Figure 1: Long-Term Treasury Bond and High-Grade Corporate Bond Yields}
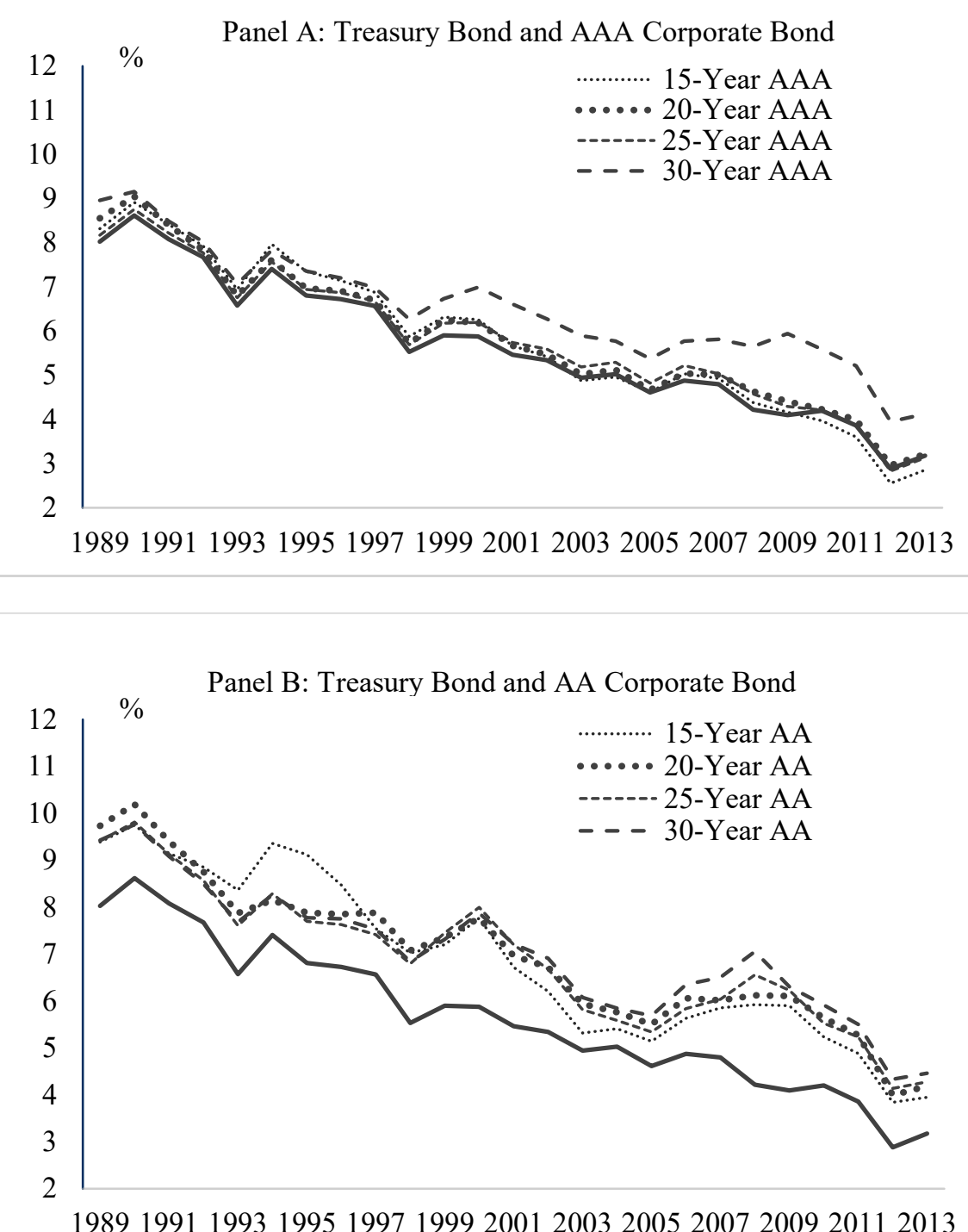
Figure 2: Pension Discount Rates and Interest Rate Benchmarks

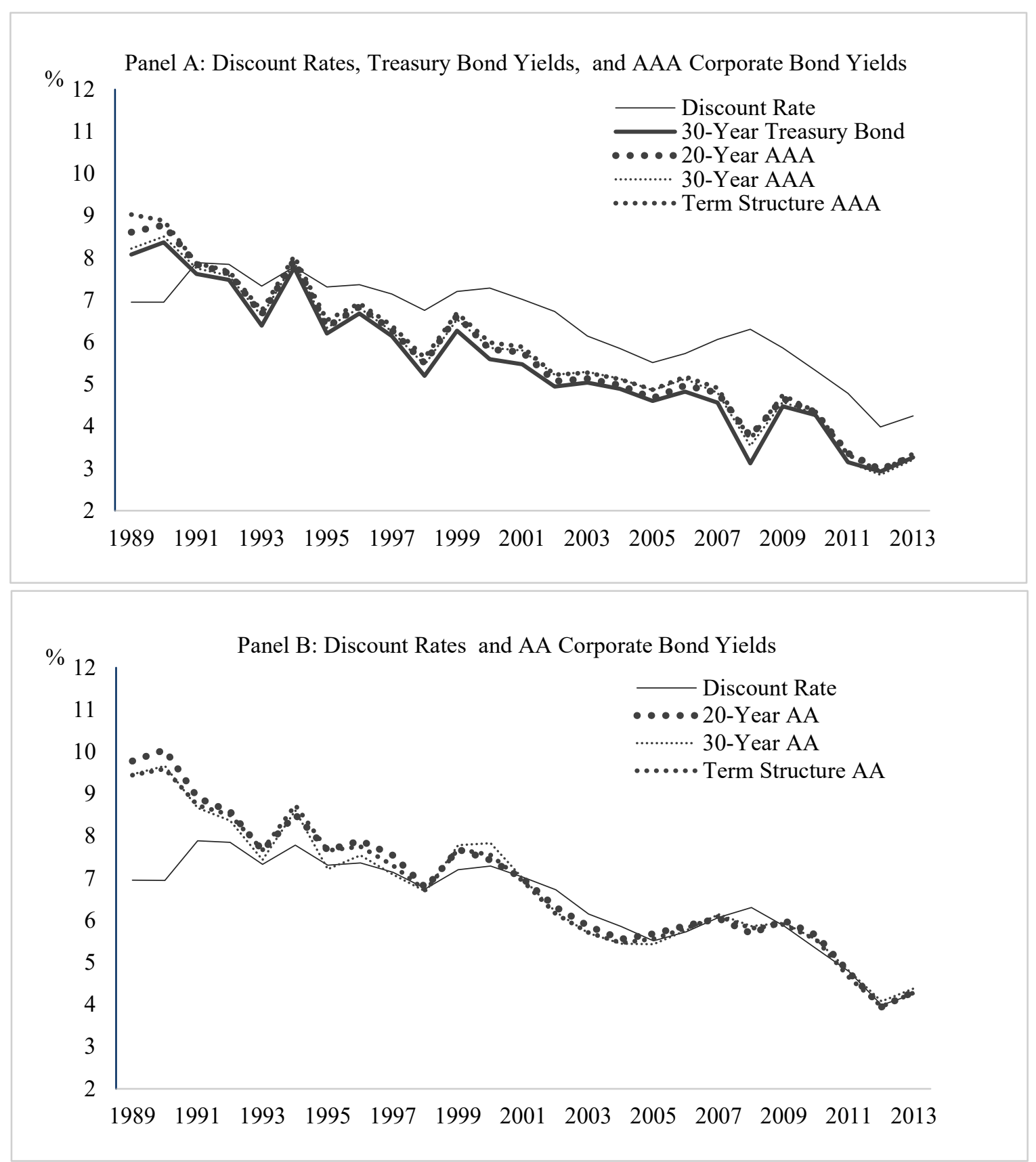

\section{Understated Pension Liabilities}

\subsection{Method for Computing Understated Pension Liabilities}

The calculation of $\mathrm{PBO}$ and $\mathrm{ABO}$ s for each individual employee requires firm level aggregate pension benefit formula parameters such as number of years to retirement $(N)$, the percentage of current salary to be received after retirement $(K)$, and current wages $(W)$. We rely on the method developed in Hann, Lu, and Subramanyam [2007] to obtain these parameters at the aggregate firm level. Then we replace the assumed pension discount rate with alternative interest rate benchmarks to obtain the new $\mathrm{PBO}$ or $\mathrm{ABO}$ values. Notice that $\mathrm{PBO}$ is defined as: 


$$
P B O=\frac{A\left(r^{\text {DISCOUNT }}, L\right) \times K \times W \times(1+g)^{N}}{\left(1+r^{\text {DISCOUNT }}\right)^{N}},
$$

where $A\left(r^{\text {DISCOUNT }}, L\right)=r^{-1}\left(1-\left(1+r^{\text {DISCOUNT }}\right)^{-L}\right)$ is the annuity factor of an $L$ period annuity at a pension discount rate of rDISCOUNT. $L$ is the life expectancy of workers after retirement, $K$ is the proportion of employees' wages that are payable given current service performed and vesting, $W, g$, and $N$ denote current wage, compensation growth rate, and number of years to retirement, respectively. $K \times W \times(1+g)^{N}$ is the expected annuity the employee will receive after retirement. We make the assumption that the average life expectancy after retirement $L$ is 15.6 Then we need to estimate three parameters: $N, K$, and $W$. First, building on the relation between $P B O$ and $A B O$ :

$$
P B O=A B O(1+g)^{N},
$$

then, we calculate $N$ as:

$$
\hat{N}=\log (P B O / A B O) / \log (1+g) .
$$

Now we can find the pension benefit formula parameters $\hat{K} \times \hat{W}$ as:

$$
\hat{K} \times \hat{W}=\frac{P B O \times\left(1+r^{D I S C O U N T}\right)^{\hat{N}}}{A\left(r^{D I S C O U N T}, \hat{L}\right) \times(1+g)^{\hat{N}}} .
$$

As a result, PBO discounted at the 30-year Treasury bond yield can be calculated as:

$$
P B O^{T B 30 Y}=\frac{A\left(r^{T B 30 Y}, \hat{L}\right) \times \hat{K} \times \hat{W} \times(1+g)^{\hat{N}}}{\left(1+r^{T B 30 Y}\right)^{\hat{N}}} .
$$

The understated $\mathrm{PBO}$ is the difference between the reported $\mathrm{PBO}$ and PBO ${ }^{\mathrm{TB} 30 \mathrm{r}}$ divided by the fiscal year-end market value ME. For overstated $\mathrm{PBO}$, or $\mathrm{PBO}>\mathrm{PBO}{ }^{\mathrm{TB} 30 Y}$, we truncate their value at zero:

$$
P C T_{-} T B 30 Y=\min \left(\frac{P B O-P B O^{T B 30 Y}}{M E}, 0\right) .
$$

Similarly, $A B O$ discounted at the 30-year Treasury bond yield can be computed as:

$$
A B O^{T B 30 Y}=\frac{A\left(r^{T B 30 Y}, \hat{L}\right) \times \hat{K} \times \hat{W}}{\left(1+r^{T B 30 Y}\right)^{\hat{N}}} .
$$

The understated $A B O$ is the difference between the reported $A B O$ and $A B O{ }^{T B 30 Y}$ divided by the fiscal year-end market value ME truncated at a value of zero:

$$
A P C T \_T B 30 Y=\min \left(\frac{A B O-A B O^{T B 30 Y}}{M E}, 0\right) .
$$

The truncation of PCT_TB3OY and APCT_TB30Y at a value of zero means that the largest value of these two measures is zero. Understated $\mathrm{PBO}$ and $\mathrm{ABO}$ s relative to long-term AAA-grade and AA-grade corporate bond yields are calculated in an analogous way.

\footnotetext{
6 See the Centres for Medicare and Medicaid Services webpage: http://www.cms.hhs.gov.
} 


\subsection{How Much Do Firms Understate Their Pension Liabilities?}

We obtain understated pension liabilities in dollar amounts and in percentages and summarize the results in Table 3. Panel A shows that the average of the understated PBOs is $\$ 141$ million using r $\mathrm{r}^{\mathrm{TB} 30 \mathrm{Y}}$ as the benchmark. The numbers become $\$ 121, \$ 122$, and $\$ 121$ million, respectively, relative to the long-term AAA-grade corporate bond yields of rAAA20Y, rAAA25Y, and rAAATM. When we scale the understated $\mathrm{PBO}$ s by fiscal-year-end market value, $\mathrm{PBO}$ are understated by $2.7 \%$ relative to the Treasury benchmark and by $2.3 \%, 2.3 \%$, and $2.3 \%$, respectively, relative to three AAA-grade corporate bond yields. PBOs are understated by $\$ 17$ million, $\$ 19$ million, and $\$ 22$ million, respectively, relative to the three AA-grade corporate bond yields. These translate into $0.4 \%, 0.4 \%$, and $0.5 \%$ of the end of fiscal year market value.

Table 3: Summary Statistics

\begin{tabular}{|c|c|c|c|c|c|c|}
\hline & $5 \%$ & $25 \%$ & Mean & Median & $75 \%$ & $95 \%$ \\
\hline Benchmark & \multicolumn{6}{|c|}{ Understated PBOs (million \$) } \\
\hline $\mathrm{r}^{\mathrm{TB} 30 \mathrm{Y}}$ & -640.6 & -82.7 & -140.5 & -16.3 & -2.2 & 0.0 \\
\hline rAAA2OY & -553.6 & -70.4 & -120.8 & -13.4 & -1.5 & 0.0 \\
\hline rAAA25Y & -564.4 & -70.6 & -121.5 & -13.0 & -1.6 & 0.0 \\
\hline rAAATM & -552.1 & -65.5 & -120.6 & -11.0 & -0.8 & 0.0 \\
\hline rAA2OY & -84.7 & -4.4 & -16.9 & 0.0 & 0.0 & 0.0 \\
\hline rAA25Y & -100.0 & -6.6 & -19.0 & -0.1 & 0.0 & 0.0 \\
\hline \multirow[t]{2}{*}{ rAATM } & -115.7 & -6.7 & -22.3 & 0.0 & 0.0 & 0.0 \\
\hline & \multicolumn{6}{|c|}{ Understated PBOs (\%) } \\
\hline$r^{\text {TB } 30 Y}$ & -10.7 & -3.2 & -2.7 & -1.2 & -0.3 & 0.0 \\
\hline rAAA2OY & -9.2 & -2.8 & -2.3 & -1.0 & -0.2 & 0.0 \\
\hline rAAA25Y & -9.5 & -2.8 & -2.3 & -1.0 & -0.2 & 0.0 \\
\hline rAAATM & -9.6 & -2.7 & -2.3 & -0.9 & -0.1 & 0.0 \\
\hline rAA2OY & -2.0 & -0.3 & -0.4 & 0.0 & 0.0 & 0.0 \\
\hline rAA25Y & -2.2 & -0.4 & -0.4 & -0.1 & 0.0 & 0.0 \\
\hline \multirow[t]{2}{*}{ rAATM } & -2.6 & -0.4 & -0.5 & 0.0 & 0.0 & 0.0 \\
\hline & \multicolumn{6}{|c|}{ Understated ABOs (million \$) } \\
\hline$r^{\text {TB } 30 Y}$ & -572.4 & -73.6 & -124.7 & -14.3 & -1.8 & 0.0 \\
\hline rAAA2OY & -493.9 & -62.3 & -106.8 & -11.7 & -1.3 & 0.0 \\
\hline rAAA25Y & -508.6 & -62.6 & -107.4 & -11.4 & -1.3 & 0.0 \\
\hline rAAATM & -499.9 & -57.9 & -107.6 & -9.6 & -0.7 & 0.0 \\
\hline rAA2OY & -76.2 & -3.8 & -15.1 & 0.0 & 0.0 & 0.0 \\
\hline rAA25Y & -88.9 & -5.8 & -16.9 & -0.1 & 0.0 & 0.0 \\
\hline \multirow[t]{2}{*}{ rAATM } & -104.2 & -6.0 & -19.9 & 0.0 & 0.0 & 0.0 \\
\hline & \multicolumn{6}{|c|}{ Understated ABOs (\%) } \\
\hline$r^{\top B 30 Y}$ & -9.5 & -2.9 & -2.4 & -1.0 & -0.2 & 0.0 \\
\hline rAAA2OY & -8.2 & -2.5 & -2.0 & -0.9 & -0.2 & 0.0 \\
\hline rAAA25Y & -8.5 & -2.4 & -2.1 & -0.9 & -0.2 & 0.0 \\
\hline rAAATM & -8.6 & -2.4 & -2.1 & -0.8 & -0.1 & 0.0 \\
\hline YAA2OY & -1.8 & -0.2 & -0.3 & 0.0 & 0.0 & 0.0 \\
\hline rAA25Y & -2.0 & -0.3 & -0.4 & -0.1 & 0.0 & 0.0 \\
\hline rAATM & -2.4 & -0.4 & -0.4 & 0.0 & 0.0 & 0.0 \\
\hline
\end{tabular}

Note: The sample covers 11,450 firm-year observations from 1,217 firms from October 1988 to June 2013. The table provides summary statistics for understated pension liability in dollar amounts and in percentages. The understated pension liabilities include projected benefit obligations (PBOs) and accumulated benefit obligations (ABOs) relative to the following interest rate benchmarks: $\mathrm{r}^{\mathrm{TB} 30 Y}$, rAAA2OY, rAAA25Y, rAAATM, $\mathrm{r}^{A A 20 Y}$, rAA25Y, and $\mathrm{r}^{\mathrm{AATM}}$. The understated pension liabilities are scaled by fiscalyear-end market value. The discount factor assumes a life expectancy of 15 years from retirement age of $65 .{ }^{* *}$ indicates significance at the $5 \%$ level; * indicates significance at the $10 \%$ level.

The patterns from understated $\mathrm{ABO}$ s essentially mirror those from $\mathrm{PBO}$. The average of the understated $A B O$ s is $\$ 125$ million using $\mathrm{r}^{\mathrm{TB} 30 \mathrm{Y}}$ as the benchmark. The numbers become $\$ 107$ million, 
$\$ 107$ million, and \$108 million, respectively, relative to the three AAA-grade corporate bond yields, rAAA20Y, rAAA25Y, and rAAATM. As a percentage of fiscal-year-end market value, ABOs are understated by $2.4 \%$ relative to the Treasury benchmark and by $2.0 \%, 2.1 \%$, and $2.1 \%$, respectively, relative to the three AAA-grade corporate bond yield benchmarks. Relative to the AA-grade corporate bond yield benchmarks, $A B O$ s are understated by $\$ 15$ million, $\$ 17$ million, and $\$ 20$ million, respectively. These hidden accumulated pension liabilities represent only $0.3 \%, 0.4 \%$, and $0.4 \%$ of the market value corresponding to the fiscal year end.

\section{Empirical Tests for the Determinants of Cost of Equity}

We begin the empirical analysis by running the following OLS regressions. The model is specified with the cost of equity COST, the simple average of COST_GLS, COST_CT, COST_PE, and COST_OJ, as the dependent variable. The independent variables include firm characteristics and pension variables. We also include calendar year and industry dummies:

$$
\begin{gathered}
\operatorname{COST}_{i t+1}=\alpha_{0}+\alpha_{1} \text { BETA }_{i t}+\alpha_{2} \text { ASTD }_{i t}+\alpha_{3} \text { ME }_{i t}+\alpha_{4} \text { BM }_{i t}+\alpha_{5} \text { MLEV }_{i t}+\alpha_{6} L_{\text {LI }} Q_{i t} \\
+\alpha_{7} \text { INTCOV }_{i t}+\alpha_{8} \text { MARGIN }_{i t}+\alpha_{9} \text { LOSS }_{i t}+\alpha_{10} \text { TRANS }_{i t}+\alpha_{11} \text { OBS }_{i t} \\
+\alpha_{12} \text { LGROW }_{i t}+\alpha_{13} \text { IND_COST }_{i t}+\alpha_{14} F S_{i t}+\alpha_{15} M C_{i t}+\alpha_{16} \text { USP }_{i t}+ \\
+\sum_{j=1}^{24} \lambda_{j}^{\text {Year }} D_{j}^{\text {Year }}+\sum_{k=1}^{43} \lambda_{k}^{\text {Industry }} D_{k}^{\text {Industry }}
\end{gathered}
$$

where USPLit denotes understated PBOs and understated $\mathrm{ABOs}$. We report the regression results for $U P B O s$ and $U A B O$ s in Panels $A$ and $B$ of Table 4, respectively.

From Model 1 in Panel A, the estimated coefficient (t-statistic) on PCT_TB30Y is -0.029 (-3.11). Despite the strong correlation of 0.58 between MC and PCT_TB30Y, the understated pension liability has incremental explanatory power. The evidence provides strong support for our hypothesis that firms with more hidden pension liabilities face a higher cost of equity. The estimate is precise with a large t-statistic. Similarly, Panel A shows that when we replace PCT_TB30Y by PCT_AAA20Y,PCT_AAA25Y, and PCT_AAATM one at a time in the regression in Equation (12), the estimates (t-statistic) are -0.032 $(-2.91),-0.031$ (-2.99), and -0.027 (-2.81), respectively.

When understated $A B O s$ are included in Equation (12) in Panel $B$, the estimates (t-statistic) on APCT_TB30Y, APCT_AAA20Y, APCT_AAA25Y, and APCT_AAATM are $-0.035(-3.26),-0.038(-3.05),-0.037$ (-3.12), and $-0.033(-2.97)$, respectively. Therefore, the empirical evidence from $A B O s$ also provides strong support for our hypothesis that firms with more hidden pension liabilities face a higher cost of equity. Overall, the empirical results suggest that understated pension liabilities relative to 30 -year Treasury bond and AAA-grade corporate bond yields significantly increase the cost of equity. This effect is incremental in the presence of other pension variables such as funded status and mandatory contributions. Similarly, all t-statistics have been adjusted for clustering-in-firm effects (Petersen, 2009). Now we examine whether understated pension liabilities relative to AA-grade corporate bond yields also affect firms' cost of equity. We run the same regression as specified in Equation (12), where USPLit now denotes, for example, PCT_AA20Y. The empirical results appear in the last three columns of Panels $A$ and $B$ in Table 4. When measured relative to AA-grade corporate bond yields, understated pension liabilities become insignificantly related to individual firms' cost of equity. 
Table 4: Implied Cost of Equity and Understated Pension Liabilities

\begin{tabular}{|c|c|c|c|c|c|c|c|}
\hline \multicolumn{8}{|c|}{ Panel A: Understated PBOs Included } \\
\hline & Model 1 & Model 2 & Model 3 & Model 4 & Model 5 & Model 6 & Model 7 \\
\hline \multirow[t]{2}{*}{ BETA } & 0.122 & 0.121 & 0.121 & 0.120 & 0.121 & 0.120 & 0.119 \\
\hline & $(2.04)^{* *}$ & $(2.04)^{* *}$ & $(2.04)^{* *}$ & $(2.02)^{* *}$ & $(2.04)^{* *}$ & $(2.01)^{* *}$ & $(2.01)^{* *}$ \\
\hline \multirow[t]{2}{*}{ ASTD } & 0.260 & 0.260 & 0.260 & 0.261 & 0.260 & 0.263 & 0.260 \\
\hline & $(2.68)^{* *}$ & $(2.69)^{* *}$ & $(2.68)^{* *}$ & $\left(2.69^{* *}\right.$ & $(2.67)^{* *}$ & $(2.71)^{* *}$ & $(2.68)^{* *}$ \\
\hline \multirow[t]{2}{*}{$M E$} & 0.058 & 0.058 & 0.058 & 0.057 & 0.060 & 0.061 & 0.060 \\
\hline & $(1.93)^{*}$ & $(1.94)^{*}$ & $(1.93)^{*}$ & $(1.92)^{*}$ & $(2.02)^{* *}$ & $(2.03)^{* *}$ & $(2.01)^{* *}$ \\
\hline \multirow[t]{2}{*}{$B M$} & 3.093 & 3.096 & 3.095 & 3.096 & 3.114 & 3.117 & 3.114 \\
\hline & $(21.73)^{* *}$ & $(21.76)^{* *}$ & $(21.73)^{* *}$ & $(21.72)^{* *}$ & $(21.85)^{* *}$ & $(21.84)^{* *}$ & $(21.87)^{* *}$ \\
\hline \multirow[t]{2}{*}{ MLEV } & 0.639 & 0.641 & 0.642 & 0.644 & 0.656 & 0.656 & 0.653 \\
\hline & $(5.11)^{* *}$ & $(5.12)^{* *}$ & $(5.13)^{* *}$ & $(5.13)^{* *}$ & $(5.21)^{* *}$ & $(5.20)^{* *}$ & $(5.17)^{* *}$ \\
\hline \multirow[t]{2}{*}{$L I Q$} & 3.159 & 3.160 & 3.156 & 3.159 & 3.166 & 3.139 & 3.155 \\
\hline & $(4.95)^{* *}$ & $(4.95)^{* *}$ & $(4.95)^{* *}$ & $(4.94)^{* *}$ & $(4.94)^{* *}$ & $(4.89)^{* *}$ & $(4.92)^{* *}$ \\
\hline \multirow[t]{2}{*}{ INTCOV } & 0.002 & 0.001 & 0.001 & 0.001 & 0.002 & 0.002 & 0.002 \\
\hline & $(1.29)$ & $(1.30)$ & $(1.30)$ & $(1.30)$ & (1.34) & (1.35) & (1.34) \\
\hline \multirow[t]{2}{*}{ MARGIN } & -1.645 & -1.646 & -1.650 & -1.653 & -1.688 & -1.692 & -1.687 \\
\hline & $(-4.33)^{* *}$ & $(-4.33)^{* *}$ & $(-4.35)^{* *}$ & $(-4.35)^{* *}$ & $(-4.46)^{* *}$ & $(-4.48)^{* *}$ & $(-4.46)^{* *}$ \\
\hline \multirow[t]{2}{*}{ LOSS } & 0.049 & 0.050 & 0.051 & 0.050 & 0.052 & 0.049 & 0.051 \\
\hline & $(0.32)$ & (0.33) & $(0.34)$ & (0.33) & $(0.34)$ & $(0.32)$ & $(0.34)$ \\
\hline \multirow[t]{2}{*}{ TRANS } & -3.740 & -3.745 & -3.737 & -3.746 & -3.761 & -3.749 & -3.757 \\
\hline & $(-3.20)^{* *}$ & $(-3.20)^{* *}$ & $(-3.20)^{* *}$ & $(-3.20)^{* *}$ & $(-3.21)^{* *}$ & $(-3.20)^{* *}$ & $(-3.21)^{* *}$ \\
\hline \multirow[t]{2}{*}{ OBS } & 0.226 & 0.227 & 0.227 & 0.227 & 0.236 & 0.237 & 0.235 \\
\hline & $(6.03)^{* *}$ & $(6.06)^{* *}$ & $(6.05)^{* *}$ & $(6.06)^{* *}$ & $(6.27)^{* *}$ & $(6.28)^{* *}$ & $(6.27)^{* *}$ \\
\hline \multirow[t]{2}{*}{ LGROW } & 10.663 & 10.664 & 10.664 & 10.662 & 10.671 & 10.678 & 10.674 \\
\hline & $(24.69)^{* *}$ & $(24.68)^{* *}$ & $(24.67)^{* *}$ & $(24.66)^{* *}$ & $(24.71)^{* *}$ & $(24.71)^{* *}$ & $(24.70)^{* *}$ \\
\hline \multirow[t]{2}{*}{ IND_COST } & 0.478 & 0.478 & 0.478 & 0.478 & 0.479 & 0.479 & 0.479 \\
\hline & $(20.72)^{* *}$ & $(20.71)^{* *}$ & $(20.71)^{* *}$ & $(20.70)^{* *}$ & $(20.69)^{* *}$ & $(20.70)^{* *}$ & $(20.68)^{* *}$ \\
\hline \multirow[t]{2}{*}{ FS } & 0.020 & 0.020 & 0.020 & 0.021 & 0.021 & 0.020 & 0.021 \\
\hline & $(3.60)^{* *}$ & $(3.65)^{* *}$ & $(3.68)^{* *}$ & $(3.80)^{* *}$ & $(3.69)^{* *}$ & $(3.65)^{* *}$ & $(3.73)^{* *}$ \\
\hline \multirow[t]{2}{*}{$M C$} & -0.309 & -0.314 & -0.318 & -0.335 & -0.373 & -0.383 & -0.384 \\
\hline & $(-4.38)^{* *}$ & $(-4.46)^{* *}$ & $(-4.57)^{* *}$ & $(-4.89)^{* *}$ & $(-5.33)^{* *}$ & $(-5.39)^{* *}$ & $(-5.57)^{* *}$ \\
\hline \multirow[t]{2}{*}{ PCT_TB30Y } & -0.029 & & & & & & \\
\hline & $(-3.11)^{* *}$ & & & & & & \\
\hline \multirow[t]{2}{*}{ PCT_AAA20Y } & & -0.032 & & & & & \\
\hline & & $(-2.91)^{* *}$ & & & & & \\
\hline \multirow[t]{2}{*}{ PCT_AAA25Y } & & & -0.031 & & & & \\
\hline & & & $(-2.99)^{* *}$ & & & & \\
\hline \multirow[t]{2}{*}{ PCT_AAATM } & & & & -0.027 & & & \\
\hline & & & & $(-2.81)^{* *}$ & & & \\
\hline PCT_AA2OY & & & & & -0.062 & & \\
\hline & & & & & $(-1.65)^{*}$ & & \\
\hline PCT_AA25Y & & & & & & -0.036 & \\
\hline & & & & & & $(-1.07)$ & \\
\hline PCT_AATM & & & & & & & -0.042 \\
\hline & & & & & & & $(-1.49)$ \\
\hline Year dummy & Yes & Yes & Yes & Yes & Yes & Yes & Yes \\
\hline Industry dummy & Yes & Yes & Yes & Yes & Yes & Yes & Yes \\
\hline Adj. $R^{2}$ & 0.699 & 0.699 & 0.699 & 0.699 & 0.699 & 0.699 & 0.699 \\
\hline Observations & 11,450 & 11,450 & 11,450 & 11,450 & 11,450 & 11,450 & 11,450 \\
\hline
\end{tabular}




\begin{tabular}{|c|c|c|c|c|c|c|c|}
\hline \multicolumn{8}{|c|}{ Panel B: Understated ABOs Included } \\
\hline & Model 1 & Model 2 & Model 3 & Model 4 & Model 5 & Model 6 & Model 7 \\
\hline BETA & $\begin{array}{c}0.120 \\
(2.03)^{* *}\end{array}$ & $\begin{array}{c}0.120 \\
(2.02)^{* *}\end{array}$ & $\begin{array}{c}0.120 \\
(2.03)^{* *}\end{array}$ & $\begin{array}{c}0.119 \\
(2.00)^{* *}\end{array}$ & $\begin{array}{c}0.122 \\
(2.04)^{* *}\end{array}$ & $\begin{array}{c}0.120 \\
(2.02)^{* *}\end{array}$ & $\begin{array}{c}0.119 \\
(2.00)^{* *}\end{array}$ \\
\hline ASTD & $\begin{array}{c}0.258 \\
(2.66)^{* *}\end{array}$ & $\begin{array}{c}0.258 \\
(2.67)^{* *}\end{array}$ & $\begin{array}{c}0.258 \\
(2.66)^{* *}\end{array}$ & $\begin{array}{c}0.259 \\
(2.67)^{* *}\end{array}$ & $\begin{array}{c}0.259 \\
(2.66)^{* *}\end{array}$ & $\begin{array}{c}0.262 \\
(2.70)^{* *}\end{array}$ & $\begin{array}{c}0.259 \\
(2.66)^{* *}\end{array}$ \\
\hline$M E$ & $\begin{array}{r}0.056 \\
(1.89)^{*}\end{array}$ & $\begin{array}{c}0.057 \\
(1.90)^{*}\end{array}$ & $\begin{array}{c}0.057 \\
(1.89)^{*}\end{array}$ & $\begin{array}{c}0.056 \\
(1.88)^{*}\end{array}$ & $\begin{array}{c}0.060 \\
(2.01)^{* *}\end{array}$ & $\begin{array}{c}0.060 \\
(2.02)^{*}\end{array}$ & $\begin{array}{r}0.060 \\
(2.00)^{*}\end{array}$ \\
\hline$B M$ & $\begin{array}{c}3.090 \\
(21.68)^{* *}\end{array}$ & $\begin{array}{c}3.093 \\
(21.70)^{* *}\end{array}$ & $\begin{array}{c}3.092 \\
(21.67)^{* *}\end{array}$ & $\begin{array}{c}3.093 \\
(21.67)^{* *}\end{array}$ & $\begin{array}{c}3.113 \\
(21.84)^{* *}\end{array}$ & $\begin{array}{c}3.116 \\
(21.83)^{* *}\end{array}$ & $\begin{array}{c}3.113 \\
(21.86)^{* *}\end{array}$ \\
\hline MLEV & $\begin{array}{c}0.637 \\
(5.09)^{* *}\end{array}$ & $\begin{array}{c}0.639 \\
(5.10)^{* *}\end{array}$ & $\begin{array}{c}0.641 \\
(5.12)^{* *}\end{array}$ & $\begin{array}{c}0.643 \\
(5.12)^{* *}\end{array}$ & $\begin{array}{c}0.655 \\
(5.20)^{* *}\end{array}$ & $\begin{array}{c}0.656 \\
(5.19)^{* *}\end{array}$ & $\begin{array}{c}0.653 \\
(5.16)^{* *}\end{array}$ \\
\hline LIQ & $\begin{array}{c}3.159 \\
(4.95)^{* *}\end{array}$ & $\begin{array}{c}3.159 \\
(4.95)^{* *}\end{array}$ & $\begin{array}{c}3.155 \\
(4.94)^{* *}\end{array}$ & $\begin{array}{c}3.158 \\
(4.94)^{* *}\end{array}$ & $\begin{array}{c}3.167 \\
(4.94)^{* *}\end{array}$ & $\begin{array}{c}3.140 \\
(4.90)^{* *}\end{array}$ & $\begin{array}{c}3.156 \\
(4.92)^{* *}\end{array}$ \\
\hline INTCOV & $\begin{array}{r}0.001 \\
(1.28)\end{array}$ & $\begin{array}{r}0.001 \\
(1.29)\end{array}$ & $\begin{array}{l}0.001 \\
(1.29)\end{array}$ & $\begin{array}{l}0.001 \\
(1.29)\end{array}$ & $\begin{array}{c}0.002 \\
(1.34)\end{array}$ & $\begin{array}{l}0.002 \\
(1.35)\end{array}$ & $\begin{array}{r}0.002 \\
(1.34)\end{array}$ \\
\hline MARGIN & $\begin{array}{c}-1.639 \\
(-4.32)^{* *}\end{array}$ & $\begin{array}{c}-1.642 \\
(-4.33)^{* *}\end{array}$ & $\begin{array}{c}-1.645 \\
(-4.34)^{* *}\end{array}$ & $\begin{array}{c}-1.647 \\
(-4.34)^{* *}\end{array}$ & $\begin{array}{c}-1.688 \\
(-4.46)^{* *}\end{array}$ & $\begin{array}{c}-1.691 \\
(-4.48)^{* *}\end{array}$ & $\begin{array}{c}-1.685 \\
(-4.46)^{* *}\end{array}$ \\
\hline LOSS & $\begin{array}{r}0.047 \\
(0.31)\end{array}$ & $\begin{array}{r}0.048 \\
(0.32)\end{array}$ & $\begin{array}{l}0.050 \\
(0.33)\end{array}$ & $\begin{array}{l}0.049 \\
(0.32)\end{array}$ & $\begin{array}{c}0.051 \\
(0.34)\end{array}$ & $\begin{array}{l}0.048 \\
(0.32)\end{array}$ & $\begin{array}{r}0.050 \\
(0.33)\end{array}$ \\
\hline TRANS & $\begin{array}{c}-3.757 \\
(-3.21)^{* *}\end{array}$ & $\begin{array}{c}-3.760 \\
(-3.22)^{* *}\end{array}$ & $\begin{array}{c}-3.751 \\
(-3.21)^{* *}\end{array}$ & $\begin{array}{c}-3.758 \\
(-3.21)^{* *}\end{array}$ & $\begin{array}{c}-3.768 \\
(-3.22)^{* *}\end{array}$ & $\begin{array}{c}-3.754 \\
(-3.21)^{* *}\end{array}$ & $\begin{array}{c}-3.764 \\
(-3.22)^{* *}\end{array}$ \\
\hline OBS & $\begin{array}{c}0.225 \\
(5.98)^{* *}\end{array}$ & $\begin{array}{c}0.226 \\
(6.02)^{* *}\end{array}$ & $\begin{array}{c}0.226 \\
(6.00)^{* *}\end{array}$ & $\begin{array}{c}0.226 \\
(6.02)^{* *}\end{array}$ & $\begin{array}{c}0.235 \\
(6.26)^{* *}\end{array}$ & $\begin{array}{c}0.236 \\
(6.27)^{* *}\end{array}$ & $\begin{array}{c}0.235 \\
(6.26)^{* *}\end{array}$ \\
\hline LGROW & $\begin{array}{c}10.662 \\
(24.68)^{* *}\end{array}$ & $\begin{array}{c}10.662 \\
(24.68)^{* *}\end{array}$ & $\begin{array}{c}10.663 \\
(24.66)^{* *}\end{array}$ & $\begin{array}{c}10.660 \\
(24.66)^{* *}\end{array}$ & $\begin{array}{c}10.669 \\
(24.71)^{* *}\end{array}$ & $\begin{array}{c}10.678 \\
(24.71)^{* *}\end{array}$ & $\begin{array}{c}10.673 \\
(24.70)^{* *}\end{array}$ \\
\hline IND_COST & $\begin{array}{c}0.478 \\
(20.72)^{* *}\end{array}$ & $\begin{array}{c}0.478 \\
(20.71)^{* *}\end{array}$ & $\begin{array}{c}0.478 \\
(20.71)^{* *}\end{array}$ & $\begin{array}{c}0.478 \\
(20.70)^{* *}\end{array}$ & $\begin{array}{c}0.479 \\
(20.68)^{* *}\end{array}$ & $\begin{array}{c}0.479 \\
(20.69)^{* *}\end{array}$ & $\begin{array}{c}0.478 \\
(20.68)^{* *}\end{array}$ \\
\hline FS & $\begin{array}{c}0.020 \\
(3.60)^{* *}\end{array}$ & $\begin{array}{c}0.020 \\
(3.66)^{* *}\end{array}$ & $\begin{array}{c}0.020 \\
(3.68)^{* *}\end{array}$ & $\begin{array}{c}0.021 \\
(3.82)^{* *}\end{array}$ & $\begin{array}{c}0.021 \\
(3.70)^{* *}\end{array}$ & $\begin{array}{c}0.020 \\
(3.65)^{* *}\end{array}$ & $\begin{array}{c}0.021 \\
(3.74)^{* *}\end{array}$ \\
\hline MC & $\begin{array}{c}-0.299 \\
(-4.20)^{* *}\end{array}$ & $\begin{array}{c}-0.306 \\
(-4.30)^{* *}\end{array}$ & $\begin{array}{c}-0.311 \\
(-4.42)^{* *}\end{array}$ & $\begin{array}{c}-0.328 \\
(-4.76)^{* *}\end{array}$ & $\begin{array}{c}-0.371 \\
(-5.28)^{* *}\end{array}$ & $\begin{array}{c}-0.380 \\
(-5.33)^{* *}\end{array}$ & $\begin{array}{c}-0.381 \\
(-5.53)^{* *}\end{array}$ \\
\hline APCT_TB30Y & $\begin{array}{c}-0.035 \\
(-3.26)^{* *}\end{array}$ & & & & & & \\
\hline APCT_AAA2OY & & $\begin{array}{c}-0.038 \\
(-3.05)^{* *}\end{array}$ & & & & & \\
\hline APCT_AAA25Y & & & $\begin{array}{c}-0.037 \\
(-3.12)^{* *}\end{array}$ & & & & \\
\hline APCT_AAATM & & & & $\begin{array}{c}-0.033 \\
(-2.97)^{* *}\end{array}$ & & & \\
\hline APCT_AA2OY & & & & & $\begin{array}{l}-0.074 \\
(-1.72)^{*}\end{array}$ & -0.046 & \\
\hline APCT_AA25Y & & & & & & $(-1.20)$ & \\
\hline APCT_AATM & & & & & & & $\begin{array}{l}-0.051 \\
(-1.60)\end{array}$ \\
\hline Year dummy & Yes & Yes & Yes & Yes & Yes & Yes & Yes \\
\hline Industry dummy & Yes & Yes & Yes & Yes & Yes & Yes & Yes \\
\hline Adj. $R^{2}$ & 0.700 & 0.699 & 0.699 & 0.699 & 0.699 & 0.699 & 0.699 \\
\hline Observations & 11,450 & 11,450 & 11,450 & 11,450 & 11,450 & 11,450 & 11,450 \\
\hline
\end{tabular}

Note: The sample covers 11,450 firm-year observations from 1,217 firms from October 1988 to June 2013. The table provides OLS regressions of individual firms' cost of equity (COST) on firm characteristics, industry cost of equity, pension variables, year dummies, and industry dummies. COST is the simple average of four individual measures of cost of equity, COST_GLS, COST_CT, COST_OJ, and COST_PE. Firm characteristics include BETA, ASTD, ME, BM, MLEV, LIQ, INTCOV, MARGIN, LOSS, TRANS, OBS, and LGROW. Industry cost of equity IND_COST is the simple average of the estimates from the four models (IND_COST_GLS, IND_COST_CT, IND_COST_OJ, and IND_COST_PE), where each estimate is the median value of individual firms' cost of equity from firms in the same industry during the fiscal year. The forty-eight industry classification is based on Fama and French [1997]. Pension variables include mandatory contributions (MC), understated PBOs (PCT_TB30Y, PCT_AAA20Y, PCTAAA_30Y, and PCT_AAATM), and understated ABOs (APCT_TB30Y, APCT_AAA20Y, APCTAAA_30Y, and APCT_AAATM). The definitions of the variables are provided in Appendix I. ** indicates significance at the $5 \%$ level; * indicates significance at the $10 \%$ level. Petersen [2009] one-dimension firm-clustered t-statistics are reported. 


\section{Instrumental Variable Analysis}

In this section, we address the endogeneity issue with respect to the significant negative relation between the cost of equity and understated pension liabilities documented thus far. The endogeneity issue takes place because pension discount rates are decision variables individual firms can choose. Our hypothesis is that firms try to hide their pension liabilities, but equity markets detect firms' attempts and demand higher expected returns. The alternative hypothesis is that those firms facing a higher cost of equity try to hide more of their pension liabilities. We now specify a system of two equations for COST and USPL as follows:

$$
\begin{gathered}
\operatorname{COST}_{i, t}=\beta_{0}+\beta_{1} U S P L_{i, t}+Z_{i, t} \bullet \beta+\sum_{j=1}^{24} D_{j}^{\text {Year }}+\sum_{k=1}^{43} D_{k}^{\text {Industry }}+\varepsilon_{\mathrm{i}, \mathrm{t}}, \\
U S P L_{i, t}=\gamma_{0}+\gamma_{1} \operatorname{COST}_{i, t}+Z_{i, t} \bullet \gamma+\sum_{j=1}^{24} D_{j}^{\text {Year }}+\sum_{k=1}^{43} I D_{k}^{\text {Industry }}+\varepsilon_{\mathrm{i}, \mathrm{t}},
\end{gathered}
$$

where $Z=[B E T A, A S T D, M E, B M, M L E V, L I Q, I N T C O V, M A R G I N, L O S S, T R A N S$, OBS, LGROW, IND_COST, TBIY, FS, MC] denotes a vector of 16 exogenous variables. COST measures the average cost of equity. USPL refers to understated PBOs (PCT_TB30Y, PCT_AAA2OY, PCT_AAA25Y, PCT_AAATM) and understated ABOs (APCT_TB30Y, APCT_AAA20Y, APCT_AAA25Y, APCT_AAATM), respectively. The two vectors of parameters to be estimated from the above system are $\beta=\left[\beta_{2} \ldots \beta_{16}\right]^{\prime}$ and $\gamma=\left[\gamma_{2} \ldots \gamma_{16}\right]^{\prime}$. We need to perform diagnostics and identify the strong instruments that can be used in predicting the two endogenous variables COST and USPL. Stock and Yogo (2002) and Stock, Wright, and Yogo (2002) suggest that the exogenous variable starts to qualify as a strong instrument at an F-statistic of 8.96. Based on the F-statistics, we confirm that BM, MLEV, LIQ, MARGIN, TRANS, OBS, LGROW, IND_COST, FS, and MC serve as strong instruments for COST. For all four measures of understated PBOs, $M A R G I N, O B S, T B I Y$, and $M C$ serve as strong instruments. Likewise, for all four measures of understated $A B O s$, the same set of variables serve as strong instruments.

In Table 5, we implement the two stage least squares (2SLS) analysis. In the 2SLS estimation, Equations (13) and (14) are estimated separately. In the equation that determines COST, the estimates (tstatistic) for four instrumented UPBOs are $-0.126(-5.57),-0.150(-5.49),-0.151$ (-5.47), and $-0.172(-5.29)$, respectively, from Models 1 to 4 in Panel A. The evidence provides strong support for our hypothesis that equity market investors detect managers' attempts to hide their pension obligations and adjust their required returns on firms' stocks accordingly. The over-identifying restrictions test statistics ( $p$ value) are: $1.20(0.55) ; 1.20(0.55) ; 1.28(0.53)$; and 1.20 (0.55), respectively. Therefore, we cannot reject the hypothesis that our model for COST is well specified.

On the other hand, in the equation that explains understated $P B O$ s, the estimates for instrumented COST are not significant for all four measures of understated PBOs from Models 1 to 4 in Panel A. The implication is that cost of equity does not affect understated pension liabilities. Therefore, the evidence does not provide support for the alternative hypothesis that firms with higher cost of equity tend to hide more of their pension liabilities. The conclusion we derive that using understated ABOs to measure understated pension liabilities is essentially the same as using understated PBOs. 7, 8

\footnotetext{
7 The three stage least squares (3SLS) estimates are similar to 2SLS estimates in magnitude.

8 We also estimate Equation (12) using four individual measures of implied cost of equity COST_GLS, COST_CT, COST_OJ, and COST_PE as the dependent variables. The results are similar.
} 
Table 5: The Determinants of Implied Cost of Equity and Understated Pension Liabilities: 2SLS Analysis

\begin{tabular}{|c|c|c|c|c|c|c|c|c|}
\hline \multicolumn{9}{|c|}{ Panel A: The Determinants of RATING and UPBOs } \\
\hline & \multicolumn{2}{|c|}{ Model 1} & \multicolumn{2}{|c|}{ Model 2} & \multicolumn{2}{|c|}{ Model 3} & \multicolumn{2}{|c|}{ Model 4} \\
\hline & COST & $\begin{array}{l}\text { PCT } \\
\text { TB30Y }\end{array}$ & COST & $\begin{array}{c}\text { PCT } \\
\text { AAA20Y }\end{array}$ & COST & $\begin{array}{c}P C T_{-} \\
\text {AAA25Y }\end{array}$ & COST & $\begin{array}{c}\text { PCT } \\
\text { AAATM }\end{array}$ \\
\hline UPBOs (instrumented) & $\begin{array}{l}-0.126 \\
(-5.57)^{* *}\end{array}$ & & $\begin{array}{l}-0.150 \\
(-5.49)^{* *}\end{array}$ & & $\begin{array}{l}-0.151 \\
(-5.47)^{* *}\end{array}$ & & $\begin{array}{l}-0.172 \\
(-5.29)^{* *}\end{array}$ & \\
\hline COST (instrumented) & & $\begin{array}{l}-0.056 \\
(-0.76)\end{array}$ & & $\begin{array}{l}-0.015 \\
(-0.25)\end{array}$ & & $\begin{array}{l}-0.040 \\
(-0.61)\end{array}$ & & $\begin{array}{l}-0.040 \\
(-0.57)\end{array}$ \\
\hline BETA & $\begin{array}{l}0.127 \\
(2.11)^{* *}\end{array}$ & & $\begin{array}{l}0.125 \\
(2.08)^{* *}\end{array}$ & & $\begin{array}{l}0.126 \\
(2.09)^{* *}\end{array}$ & & $\begin{array}{l}0.123 \\
(2.01)^{* *}\end{array}$ & \\
\hline ASTD & $\begin{array}{l}0.266 \\
(2.75)^{* *}\end{array}$ & $\begin{array}{l}-0.040 \\
(-0.22)\end{array}$ & $\begin{array}{l}0.270 \\
(2.78)^{* *}\end{array}$ & $\begin{array}{l}-0.031 \\
(-0.20)\end{array}$ & $\begin{array}{l}0.267 \\
(2.74)^{* *}\end{array}$ & $\begin{array}{l}-0.043 \\
(-0.26)\end{array}$ & $\begin{array}{l}0.270 \\
(2.74)^{* *}\end{array}$ & $\begin{array}{l}-0.030 \\
(-0.16)\end{array}$ \\
\hline ME & $\begin{array}{l}0.047 \\
(1.64)\end{array}$ & $\begin{array}{l}-0.065 \\
(-1.27)\end{array}$ & $\begin{array}{l}0.049 \\
(1.70)^{*}\end{array}$ & $\begin{array}{l}-0.041 \\
(-0.90)\end{array}$ & $\begin{array}{l}0.047 \\
(1.64)\end{array}$ & $\begin{array}{l}-0.052 \\
(-1.12)\end{array}$ & $\begin{array}{l}0.044 \\
(1.50)\end{array}$ & $\begin{array}{l}-0.073 \\
(-1.49)\end{array}$ \\
\hline BM & $\begin{array}{l}2.998 \\
(21.27)^{* *}\end{array}$ & $\begin{array}{l}-0.626 \\
(-1.52)\end{array}$ & $\begin{array}{l}3.012 \\
(21.31)^{* *}\end{array}$ & $\begin{array}{l}-0.517 \\
(-1.46)\end{array}$ & $\begin{array}{l}2.999 \\
(21.17)^{* *}\end{array}$ & $\begin{array}{l}-0.541 \\
(-1.48)\end{array}$ & $\begin{array}{l}2.988 \\
(20.64)^{* *}\end{array}$ & $\begin{array}{l}-0.524 \\
(-1.31)\end{array}$ \\
\hline LLEV & $\begin{array}{l}0.564 \\
(4.33)^{* *}\end{array}$ & $\begin{array}{l}-0.788 \\
(-2.89)^{* *}\end{array}$ & $\begin{array}{l}0.567 \\
(4.35)^{* *}\end{array}$ & $\begin{array}{l}-0.668 \\
(-2.83)^{* *}\end{array}$ & $\begin{array}{l}0.567 \\
(4.33)^{* *}\end{array}$ & $\begin{array}{l}-0.655 \\
(-2.73)^{* *}\end{array}$ & $\begin{array}{l}0.558 \\
(4.14)^{* *}\end{array}$ & $\begin{array}{l}-0.623 \\
(-2.33)^{* *}\end{array}$ \\
\hline LIQ & $\begin{array}{l}3.136 \\
(4.87)^{*}\end{array}$ & & $\begin{array}{l}3.139 \\
(4.82)^{*}\end{array}$ & & $\begin{array}{l}3.115 \\
(4.80)^{*}\end{array}$ & & $\begin{array}{l}3.174 \\
(4.77)^{*}\end{array}$ & \\
\hline INTCOV & & $\begin{array}{l}-0.003 \\
(-1.45)\end{array}$ & & $\begin{array}{l}-0.002 \\
(-1.07)\end{array}$ & & $\begin{array}{l}-0.002 \\
(-1.27)\end{array}$ & & $\begin{array}{l}-0.002 \\
(-1.12)\end{array}$ \\
\hline MARGIN & $\begin{array}{l}-1.434 \\
(-3.66)^{* *}\end{array}$ & $\begin{array}{l}1.983 \\
(3.59)^{* *}\end{array}$ & $\begin{array}{l}-1.434 \\
(-3.65)^{* *}\end{array}$ & $\begin{array}{l}1.719 \\
(3.57)^{* *}\end{array}$ & $\begin{array}{l}-1.437 \\
(-3.66)^{* *}\end{array}$ & $\begin{array}{l}1.665 \\
(3.39)^{* *}\end{array}$ & $\begin{array}{l}-1.393 \\
(-3.48)^{* *}\end{array}$ & $\begin{array}{l}1.736 \\
(3.22)^{* *}\end{array}$ \\
\hline LOSS & & $\begin{array}{l}0.072 \\
(0.26)\end{array}$ & & $\begin{array}{l}0.129 \\
(0.53)\end{array}$ & & $\begin{array}{l}0.155 \\
(0.63)\end{array}$ & & $\begin{array}{l}0.171 \\
(0.62)\end{array}$ \\
\hline TRANS & $\begin{array}{l}-3.769 \\
(-3.23)^{* *}\end{array}$ & $\begin{array}{l}0.092 \\
(0.05)\end{array}$ & $\begin{array}{l}-3.749 \\
(-3.21)^{* *}\end{array}$ & $\begin{array}{l}0.405 \\
(0.24)\end{array}$ & $\begin{array}{l}-3.740 \\
(-3.20)^{* *}\end{array}$ & $\begin{array}{l}0.363 \\
(0.21)\end{array}$ & $\begin{array}{l}-3.753 \\
(-3.16)^{* *}\end{array}$ & $\begin{array}{l}0.283 \\
(0.15)\end{array}$ \\
\hline OBS & $\begin{array}{l}0.180 \\
(5.30)^{* *}\end{array}$ & $\begin{array}{l}-0.342 \\
(-4.63)^{* *}\end{array}$ & $\begin{array}{l}0.184 \\
(5.43)^{* *}\end{array}$ & $\begin{array}{l}-0.260 \\
(-4.11)^{* *}\end{array}$ & $\begin{array}{l}0.180 \\
(5.28)^{* *}\end{array}$ & $\begin{array}{l}-0.289 \\
(-4.42)^{* *}\end{array}$ & $\begin{array}{l}0.172 \\
(4.95)^{* *}\end{array}$ & $\begin{array}{l}-0.300 \\
(-4.21)^{* *}\end{array}$ \\
\hline LGROW & $\begin{array}{l}10.593 \\
(24.57)^{* *}\end{array}$ & $\begin{array}{l}-0.150 \\
(-0.14)\end{array}$ & $\begin{array}{l}10.579 \\
(24.49)^{* *}\end{array}$ & $\begin{array}{l}-0.562 \\
(-0.60)\end{array}$ & $\begin{array}{l}10.581 \\
(24.39)^{* *}\end{array}$ & $\begin{array}{l}-0.291 \\
(-0.30)\end{array}$ & $\begin{array}{l}10.531 \\
(24.03)^{* *}\end{array}$ & $\begin{array}{l}-0.500 \\
(-0.47)\end{array}$ \\
\hline IND_ & $\begin{array}{l}0.475 \\
(20.61)^{* *}\end{array}$ & & $\begin{array}{l}0.477 \\
(20.52)^{* *}\end{array}$ & & $\begin{array}{l}0.476 \\
(20.51)^{* *}\end{array}$ & & $\begin{array}{l}0.475 \\
(20.32)^{* *}\end{array}$ & \\
\hline TB $1 Y$ & $\begin{array}{l}0.125 \\
(3.50)^{* *}\end{array}$ & $\begin{array}{l}0.696 \\
(9.50)^{* *}\end{array}$ & $\begin{array}{l}0.123 \\
(3.44)^{* *}\end{array}$ & $\begin{array}{l}0.569 \\
(9.10)^{* *}\end{array}$ & $\begin{array}{l}0.130 \\
(3.58)^{* *}\end{array}$ & $\begin{array}{l}0.615 \\
(9.38)^{* *}\end{array}$ & $\begin{array}{l}0.142 \\
(3.73)^{* *}\end{array}$ & $\begin{array}{l}0.608 \\
(9.02)^{* *}\end{array}$ \\
\hline FS & $\begin{array}{l}0.019 \\
(3.32)^{* *}\end{array}$ & $\begin{array}{l}-0.011 \\
(-0.45)\end{array}$ & $\begin{array}{l}0.021 \\
(3.50)^{* *}\end{array}$ & $\begin{array}{l}0.004 \\
(0.21)\end{array}$ & $\begin{array}{l}0.022 \\
(3.52)^{* *}\end{array}$ & $\begin{array}{l}0.008 \\
(0.39)\end{array}$ & $\begin{array}{l}0.029 \\
(3.85)^{* *}\end{array}$ & $\begin{array}{l}0.048 \\
(2.14)^{* *}\end{array}$ \\
\hline MC & & $\begin{array}{l}3.221 \\
(13.40)^{* *}\end{array}$ & & $\begin{array}{l}2.702 \\
(12.89)^{* *}\end{array}$ & & $\begin{array}{l}2.688 \\
(12.43)^{* *}\end{array}$ & & $\begin{array}{l}2.355 \\
(9.93)^{* *}\end{array}$ \\
\hline Year Dummies & Yes & Yes & Yes & Yes & Yes & Yes & Yes & Yes \\
\hline Industry Dummies & Yes & Yes & Yes & Yes & Yes & Yes & Yes & Yes \\
\hline $\begin{array}{l}\text { Over-Identifying } \\
\text { Restriction Tests } \\
\text { Test Statistics ( } p \text {-value) }\end{array}$ & $\begin{array}{c}1.20 \\
(0.55)\end{array}$ & $\begin{array}{c}0.56 \\
(0.75)\end{array}$ & $\begin{array}{c}1.20 \\
(0.55)\end{array}$ & $\begin{array}{c}0.35 \\
(0.84)\end{array}$ & $\begin{array}{c}1.28 \\
(0.53)\end{array}$ & $\begin{array}{c}0.44 \\
(0.80)\end{array}$ & $\begin{array}{c}1.20 \\
(0.55)\end{array}$ & $\begin{array}{c}0.16 \\
(0.92)\end{array}$ \\
\hline $\mathbf{R}^{2}$ & 0.619 & 0.325 & 0.619 & 0.314 & 0.615 & 0.306 & 0.603 & 0.278 \\
\hline Observations & 11,450 & 11,450 & 11,450 & 11,450 & 11,450 & 11,450 & 11,450 & 11,450 \\
\hline
\end{tabular}




\begin{tabular}{|c|c|c|c|c|c|c|c|c|}
\hline \multicolumn{9}{|c|}{ Panel B: The Determinants of RATING and UABOs } \\
\hline & \multicolumn{2}{|c|}{ Model 1} & \multicolumn{2}{|c|}{ Model 2} & \multicolumn{2}{|c|}{ Model 3} & \multicolumn{2}{|c|}{ Model 4} \\
\hline & COST & $\begin{array}{l}\text { APCT } \\
\text { TB30Y }\end{array}$ & COST & $\begin{array}{c}\text { APCT }_{-} \\
\text {AAA2OY }\end{array}$ & COST & $\begin{array}{c}\text { APCT } \\
\text { AAA25Y }\end{array}$ & COST & $\begin{array}{l}\text { APCT } \\
\text { AAATM }\end{array}$ \\
\hline UPBOs (instrumented) & $\begin{array}{c}-0.140 \\
(-5.57)^{* *}\end{array}$ & & $\begin{array}{c}-0.166 \\
(-5.49)^{* *}\end{array}$ & & $\begin{array}{c}-0.167 \\
(-5.47)^{* *}\end{array}$ & & $\begin{array}{c}-0.190 \\
(-5.30)^{* *}\end{array}$ & \\
\hline COST (instrumented) & & $\begin{array}{l}-0.060 \\
(-0.89)\end{array}$ & & $\begin{array}{l}-0.023 \\
(-0.40)\end{array}$ & & $\begin{array}{l}-0.043 \\
(-0.72)\end{array}$ & & $\begin{array}{l}-0.043 \\
(-0.67)\end{array}$ \\
\hline BETA & $\begin{array}{c}0.121 \\
(2.01)^{* *}\end{array}$ & & $\begin{array}{c}0.120 \\
(1.98)^{* *}\end{array}$ & & $\begin{array}{c}0.120 \\
(1.99)^{* *}\end{array}$ & & $\begin{array}{c}0.115 \\
(1.87)^{*}\end{array}$ & \\
\hline ASTD & $\begin{array}{c}0.260 \\
(2.69)^{* *}\end{array}$ & $\begin{array}{l}-0.095 \\
(-0.58)\end{array}$ & $\begin{array}{c}0.262 \\
(2.71)^{* *}\end{array}$ & $\begin{array}{l}-0.083 \\
(-0.58)\end{array}$ & $\begin{array}{c}0.260 \\
(2.67)^{* *}\end{array}$ & $\begin{array}{l}-0.093 \\
(-0.62)\end{array}$ & $\begin{array}{c}0.263 \\
(2.67)^{* *}\end{array}$ & $\begin{array}{l}-0.079 \\
(-0.49)\end{array}$ \\
\hline ME & $\begin{array}{l}0.044 \\
(1.51)\end{array}$ & $\begin{array}{c}-0.084 \\
(-1.82)^{*}\end{array}$ & $\begin{array}{l}0.045 \\
(1.57)\end{array}$ & $\begin{array}{l}-0.059 \\
(-1.44)\end{array}$ & $\begin{array}{l}0.044 \\
(1.51)\end{array}$ & $\begin{array}{c}-0.069 \\
(-1.66)^{*}\end{array}$ & $\begin{array}{r}0.040 \\
(1.37)\end{array}$ & $\begin{array}{c}-0.086 \\
(-1.93)^{*}\end{array}$ \\
\hline BM & $\begin{array}{c}2.996 \\
(21.28)^{* *}\end{array}$ & $\begin{array}{l}-0.547 \\
(-1.47)\end{array}$ & $\begin{array}{c}3.001 \\
(21.31)^{* *}\end{array}$ & $\begin{array}{l}-0.453 \\
(-1.39)\end{array}$ & $\begin{array}{c}2.996 \\
(21.16)^{* *}\end{array}$ & $\begin{array}{l}-0.479 \\
(-1.43)\end{array}$ & $\begin{array}{c}2.986 \\
(20.67)^{* *}\end{array}$ & $\begin{array}{l}-0.463 \\
(-1.28)\end{array}$ \\
\hline $\begin{array}{l}\text { LLEV } \\
\text { BB }\end{array}$ & 0.564 & -0.707 & 0.567 & -0.603 & 0.567 & -0.587 & 0.558 & -0.558 \\
\hline LIQ & $\begin{array}{l}(4.32)^{* *} \\
3.112 \\
(4.81)^{*}\end{array}$ & $(-2.82)^{* *}$ & $\begin{array}{c}(4.34)^{* *} \\
3.107 \\
(4.76)^{* *}\end{array}$ & $(-2.77)^{* *}$ & $\begin{array}{c}(4.33)^{* *} \\
3.084 \\
(4.73)^{*}\end{array}$ & $(-2.65)^{* *}$ & $\begin{array}{l}(4.15)^{* *} \\
3.126 \\
(4.68)^{*}\end{array}$ & $(-2.28)^{* *}$ \\
\hline INTCOV & & $\begin{array}{l}-0.002 \\
(-1.42)\end{array}$ & & $\begin{array}{l}-0.002 \\
(-1.10)\end{array}$ & & $\begin{array}{l}-0.002 \\
(-1.28)\end{array}$ & & $\begin{array}{l}-0.002 \\
(-1.12)\end{array}$ \\
\hline MARGIN & $\begin{array}{c}-1.433 \\
(-3.66)^{* *}\end{array}$ & $\begin{array}{c}1.761 \\
(3.66)^{* *}\end{array}$ & $\begin{array}{c}-1.437 \\
(-3.66)^{* *}\end{array}$ & $\begin{array}{c}1.514 \\
(3.57)^{* *}\end{array}$ & $\begin{array}{c}-1.438 \\
(-3.67)^{* *}\end{array}$ & $\begin{array}{c}1.477 \\
(3.41)^{* *}\end{array}$ & $\begin{array}{c}-1.391 \\
(-3.48)^{* *}\end{array}$ & $\begin{array}{c}1.561 \\
(3.28)^{* *}\end{array}$ \\
\hline LOSS & & $\begin{array}{l}0.021 \\
(0.08)\end{array}$ & & $\begin{array}{l}0.073 \\
(0.33)\end{array}$ & & $\begin{array}{l}0.095 \\
(0.42)\end{array}$ & & $\begin{array}{l}0.105 \\
(0.42)\end{array}$ \\
\hline TRANS & $\begin{array}{c}-3.833 \\
(-3.28)^{* *}\end{array}$ & $\begin{array}{l}-0.399 \\
(-0.23)\end{array}$ & $\begin{array}{c}-3.815 \\
(-3.26)^{* *}\end{array}$ & $\begin{array}{l}-0.072 \\
(-0.05)\end{array}$ & $\begin{array}{c}-3.801 \\
(-3.24)^{* *}\end{array}$ & $\begin{array}{l}-0.065 \\
(-0.04)\end{array}$ & $\begin{array}{c}-3.819 \\
(-3.22)^{* *}\end{array}$ & $\begin{array}{l}-0.110 \\
(-0.06)\end{array}$ \\
\hline OBS & $\begin{array}{c}0.178 \\
(5.25)^{* *}\end{array}$ & $\begin{array}{c}-0.315 \\
(-4.82)^{* *}\end{array}$ & $\begin{array}{c}0.182 \\
(5.38)^{* *}\end{array}$ & $\begin{array}{c}-0.242 \\
(-4.29)^{* *}\end{array}$ & $\begin{array}{c}0.178 \\
(5.23)^{* *}\end{array}$ & $\begin{array}{c}-0.268 \\
(-4.60)^{* *}\end{array}$ & $\begin{array}{c}0.170 \\
(4.90)^{* *}\end{array}$ & $\begin{array}{c}-0.275 \\
(-4.35)^{* *}\end{array}$ \\
\hline LGROW & $\begin{array}{c}10.593 \\
(24.61)^{* *}\end{array}$ & $\begin{array}{l}-0.021 \\
(-0.02)\end{array}$ & $\begin{array}{c}10.579 \\
(24.55)^{* *}\end{array}$ & $\begin{array}{l}-0.404 \\
(-0.48)\end{array}$ & $\begin{array}{c}10.581 \\
(24.45)^{* *}\end{array}$ & $\begin{array}{l}-0.172 \\
(-0.19)\end{array}$ & $\begin{array}{c}10.534 \\
(24.17)^{* *}\end{array}$ & $\begin{array}{l}-0.361 \\
(-0.38)\end{array}$ \\
\hline IND_COST & $\begin{array}{c}0.475 \\
(20.58)^{* *}\end{array}$ & & $\begin{array}{c}0.477 \\
(20.50)^{* *}\end{array}$ & & $\begin{array}{c}0.475 \\
(20.49)^{* *}\end{array}$ & & $\begin{array}{c}0.475 \\
(20.30)^{* *}\end{array}$ & \\
\hline TB $1 Y$ & $\begin{array}{c}0.124 \\
(3.47)^{* *}\end{array}$ & $\begin{array}{c}0.618 \\
(9.42)^{* *}\end{array}$ & $\begin{array}{c}0.122 \\
(3.41)^{* *}\end{array}$ & $\begin{array}{c}0.508 \\
(8.97)^{* *}\end{array}$ & $\begin{array}{c}0.129 \\
(3.55)^{* *}\end{array}$ & $\begin{array}{c}0.549 \\
(9.27)^{* *}\end{array}$ & $\begin{array}{c}0.140 \\
(3.69)^{* *}\end{array}$ & $\begin{array}{c}0.539 \\
(8.89)^{* *}\end{array}$ \\
\hline FS & $\begin{array}{c}0.019 \\
(3.33)^{* *}\end{array}$ & $\begin{array}{l}-0.009 \\
(-0.41)\end{array}$ & $\begin{array}{c}0.021 \\
(3.52)^{* *}\end{array}$ & $\begin{array}{l}0.005 \\
(0.25)\end{array}$ & $\begin{array}{c}0.022 \\
(3.54)^{* *}\end{array}$ & $\begin{array}{l}0.008 \\
(0.44)\end{array}$ & $\begin{array}{c}0.028 \\
(3.86)^{* *}\end{array}$ & $\begin{array}{c}0.043 \\
(2.13)^{* *}\end{array}$ \\
\hline MC & & $\begin{array}{c}2.886 \\
(13.42)^{* *}\end{array}$ & & $\begin{array}{c}2.442 \\
(12.91)^{* *}\end{array}$ & & $\begin{array}{c}2.427 \\
(12.45)^{* *}\end{array}$ & & $\begin{array}{c}2.130 \\
(10.07)^{* *}\end{array}$ \\
\hline Year Dummies & Yes & Yes & Yes & Yes & Yes & Yes & Yes & Yes \\
\hline Industry Dummies & Yes & Yes & Yes & Yes & Yes & Yes & Yes & Yes \\
\hline $\begin{array}{l}\text { Over-Identifying } \\
\text { Restriction Tests } \\
\text { Test Statistics ( } \mathrm{p} \text {-value) }\end{array}$ & $\begin{array}{l}1.19 \\
(0.55)\end{array}$ & $\begin{array}{c}0.14 \\
(0.93)\end{array}$ & $\begin{array}{l}1.34 \\
(0.51)\end{array}$ & $0.07(0.97)$ & $1.24(0.54)$ & $\begin{array}{c}0.11 \\
(0.95)\end{array}$ & $\begin{array}{c}1.16 \\
(0.56)\end{array}$ & $\begin{array}{c}0.03 \\
(0.99)\end{array}$ \\
\hline $\mathbf{R}^{2}$ & 0.620 & 0.337 & 0.617 & 0.324 & 0.616 & 0.316 & 0.606 & 0.288 \\
\hline Observations & 11,450 & 11,450 & 11,450 & 11,450 & 11,450 & 11,450 & 11,450 & 11,450 \\
\hline
\end{tabular}

Note: The sample covers 11,450 firm-year observations from 1,217 firms from October 1988 to June 2013. This table reports the two-stage least square (2SLS) regressions for the determinants of individual firms' cost of equity and understated pension liabilities. In Panel A, the two structural equations are (1) COST = linear function(USPL, Z) and (2) UPBO=linear function(COST, Z), where COST is the simple average of four individual measures of cost of equity (COST_GLS, COST_CT, COST_OJ, and COST PE). UPBO refers to understated PBOs (PCT TB3OY, PCT AAA20Y, PCT AAA25Y, and PCT AAATM). Z is the set of exogenous variables, including the constant intercept, ME_INF, COVERAGE, MARGIN, LLEV, PPE, BETA, R2, TRANS, TBIY, FS, MC, year dummies, and industry dummies. In Panel $B$, the two structural equations are (1) COST = linear function(UABO, Z) and (2) $U A B O=$ linear function(COST, Z), where UABO refers to understated ABOs (APCT_TB30Y, APCT_AAA20Y, APCT_AAA25Y, and APCT_AAATM). TBIY denotes the yield on one-year Treasury notes. The table also reports the over-identifying restriction tests for the model specifications. ${ }^{* *}$ indicates significance at the $5 \%$ level; * indicates significance at the $10 \%$ level. Petersen [2009] one-dimension firm-clustered t-statistics are reported. 


\section{Conclusions}

Defined benefit corporate pension plans were once popular ways to arrange retirement benefits for U.S. employees. That has changed over time as more firms switch to defined contribution planspassing the risk of having sufficient funds to finance retirement to their employees. Indeed, the advisory firm Willis Towers Watson, estimates that only about $14 \%$ of Fortune 500 firms offered a defined benefit plan in some form to their employees in 2019 versus $59 \%$ in 1998. ${ }^{9}$ Nevertheless, the amount of assets in private defined benefit plans of all types in the USA remains huge with almost $\$ 3$ trillion in assets across all defined benefit plans as of 2018 according to a 2021 U.S. Department of Labor report. The valuation of the corresponding huge defined benefit pension obligations critically depends on pension discount rates, among other pension parameters, because of the long-term nature of pension obligations. Firms have considerable discretion in choosing their pension discount rate. We examine the value of $\mathrm{PBO}$ and $\mathrm{ABO}$ s if firms strictly follow the guideline interest rate benchmarks and compare them with reported $\mathrm{PBO}$ s and $\mathrm{ABOs}$. We find that most firms in our sample choose pension discount rates that are higher than the 30-year Treasury bond and 20-year and 25year AAA-grade corporate bond yields. This leads to understated pension PBOs and ABOs. We further show that these hidden pension liabilities significantly increase firms' implied cost of equity, suggesting that the market is not misled by intentional or unintentional discretion in choosing pension discount rates. Our results are robust after taking into account traditional control variables and important pension information such as funded status and mandatory contributions.

Unlike standard control variables, pension information appears in the notes of 10-K reports. Therefore, the disclosure level is much lower than earnings-based information risk proxies that directly appear in financial statements. Hirst and Hopkins [1998] and Davis-Friday and Folami [1999] show that the way accounting information is presented, organized, and processed affects valuation by investors and analysts. Plumlee [2003] concludes that complexity reduces analysts' use of information. Users of financial reports need to sort through voluminous notes to effectively forecast future earnings and adjust their valuation of firms. In addition, pension related numbers and their implications can be difficult for even sophisticated investors to gauge and reconcile with financial statements. Despite all these difficulties, our results show that stock market investors detect these hidden liabilities and adjust their valuation and earnings forecasts accordingly.

\section{References}

Andonov, A., R. Baver, and M. Cremers, 2013, Pension fund asset allocation and liability discount rates: Camouflage and reckless risk taking by U.S. public plans?, Working Paper, University of Notre Dame, IN 46556.

Bergstresser, D., M. Desai, and J. Rauh, 2006, Earnings manipulation, pension assumptions, and managerial investment decisions, Quarterly Journal of Economics 121, 157-195.

Bhattacharya, U., H. Daouk, and M. Welker, 2003, The world price of earnings opacity, Accounting Review 78, 641-678.

Black, F., 1989, Should you use stocks to hedge your pension liability?, Financial Analyst Journal, January/February, 10-12.

Botosan, C., and M. Plumlee, 2005, Assessing alternative proxies for the expected risk premium, Accounting Review 80, 21-53.

9 McFarland, Brendan, "Retirement Offerings in the Fortune 500: 1998-2019," Willis Towers Watson,

https://www.willistowerswatson.com/en-US/Insights/2020/06/retirement-offerings-in-the-fortune-500-1998-2019 
Botosan, C., M. Plumlee, and Y. Xie, 2004, The role of information precision in determining the cost of equity capital, Review of Accounting Studies 9, 233-259.

Brown, J., and D. Wilcox, 2009, Discounting state and local pension liabilities, American Economic Review 99, 538-542.

Campbell, J., D. Dhaliwal, and W. Schwartz, Jr., 2012, Financing constraints and the cost of capital: Evidence from the funding of corporate pension plans, Review of Financial Studies 25, 868-912.

Claus, J., and J. Thomas, 2001, Equity premia as low as three percent? Evidence from analysts' earnings forecasts for domestic and international stock markets, Journal of Finance 56, 1629-1666.

Core, J., W. Guay, and R. Verdi, 2008, Is accruals quality priced as a factor?, Journal of Accounting and Economics 46, 2-22.

Coronado, J., and S. Sharpe, 2003, Did pension plan accounting contribute to a stock market bubble?, Brookings Papers on Economic Activity, 323-371.

Davis-Friday, P., and L. Folami, 1999, The value relevance of financial statement recognition vs. disclosure: Evidence from SFAS No. 106, Accounting Review 74, 403-423.

Diamond, D., and R. Verrecchia, 1991, Disclosure, liquidity, and the cost of capital, Journal of Finance 46, 1325-1359.

Easley, D., and M. O'Hara, 2004, Information and the cost of capital, Journal of Finance 59, 15531583.

Easton, P., 2004, PE ratios, PEG ratios, and estimating the implied expected rate of return on equity capital, Accounting Review 79, 73-95.

Ecker, F., J. Francis, I. Kim, P. Olsson, and K. Schipper, 2006, A returns-based representation of earnings quality, Accounting Review 81, 749-780.

Elton, E, 1999, Expected return, realized return and asset pricing tests, Journal of Finance 54, 11991220.

Fama, E., and K. French, 1997, Industry costs of equity, Journal of Financial Economics 43, 153-194.

Feldstein, M., and R. Morck, 1983, Pension funding decisions, interest rate assumptions, and share prices, In: Bodie, Z., and J. Shoven (Eds.), Financial Aspects of the United States Pension System, National Bureau of Economic Research Project Report Series, University of Chicago Press, Chicago, Illinois, pp. 177-210.

Francis, J., R. LaFond, P. Olsson, and K. Schipper, 2004, Costs of equity and earnings attributes, Accounting Review 79, 967-1010.

Francis, J., R. LaFond, P. Olsson, and K. Schipper, 2005, The market pricing of accruals quality, Journal of Accounting and Economics 39, 295-327.

Franzoni, F., and J. Marín, 2006, Pension plan funding and stock market efficiency, Journal of Finance $61,921-952$.

Gebhardt, W., C. Lee, and B., Swaminathan, 2001, Toward an implied cost of capital, Journal of Accounting Research 39, 135-176. 
Gode, D., and P. Mohanram, 2003, Inferring the cost of capital using the Ohlson-Juettner model, Review of Accounting Studies 8, 399-431.

Gordon, J., 1962, The investment, financing and valuation of the corporation, Irwin, Homewood, IL.

Hann, R., Y. Lu, and K. Subramanyam, 2007, Uniformity versus flexibility: Evidence from pricing of the pension obligation, Accounting Review 82, 107-137.

Hirst, D., and P. Hopkins, 1998, Comprehensive income reporting and analysts' valuation judgments, Journal of Accounting Research 36, 47-75.

Lambert, R., C. Leuz, and R. Verrecchia, 2007, Accounting information, disclosure, and the cost of capital, Journal of Accounting Research 45, 385-420.

Leuz, C., and P. Wysocki, 2008, Economic consequences of financial reporting and disclosure regulation: A review and suggestions for future research, Working Paper, University of Chicago, Chicago, IL 60637.

Liu, M., and P. Wysocki, 2008, Cross-sectional determinants of information quality proxies and cost of capital, AAA 2008 Financial Accounting and Reporting Section (FARS) Paper, Pennsylvania State University, PA 16802.

Lucas, D., and S. Zeldes, 2006, Valuing and hedging defined benefit pension obligations: The role of stocks revisited, Working Paper, Massachusetts Institute of Technology, Cambridge, MA 02142.

Lucas, D., and S. Zeldes, 2009, How should public pension plans invest?, American Economic Review 99, 527-532.

Mathur, R., G. Jonas, and M. LaMonte, 2006, Pension reform will increase funding requirements for under-funded U.S. pension plans, Moody's Special Comment.

McFarland, Brendan, "Retirement Offerings in the Fortune 500: 1998-2019," Willis Towers Watson, https://www.willistowerswatson.com/en-US/Insights/2020/06/retirement-offerings-in-the-fortune-5001998-2019

Mclnnis, J., 2010, Earnings smoothness, average returns, and implied cost of equity capital, Accounting Review 85, 315-341.

Nichols, D., 2006, Fundamental risk or information risk? An analysis of the residual accrual volatility factor, Working Paper, Cornell University, NY 14853.

Novy-Marx, R., and J. Rauh, 2009, The liabilities and risks of state-sponsored pension plans, Journal of Economic Perspectives 23, 191-210.

Novy-Marx, R., and J. Rauh, 2011, Public pension promises: How big are they and what are they worth?, Journal of Finance 66, 1211-1249.

Ogneva, M., 2012, Accrual quality, realized returns, and expected returns: The importance of controlling for cash flow shocks, Accounting Review 87, 1415-1444.

O'Hara, M., 2003, Presidential address: Liquidity and price discovery, Journal of Finance 58, 13351354.

Ohlson, J., 1980, Financial ratios and the probabilistic prediction of bankruptcy, Journal of Accounting Research 18, 109-131. 
Ohlson, J., and B. Juettner-Nauroth, 2005, Expected EPS and EPS growth as determinants of value, Review of Accounting Studies 10, 349-365.

Petersen, M., 2009, Estimating standard errors in finance panel data sets: Comparing approaches, Review of Financial Studies 22, 435-480.

Picconi, M., 2006, The perils of pensions: Does pension accounting lead investors and analysts astray? Accounting Review 81, 925-955.

Plumlee, M. 2003, The effect of information complexity on analysts' use of that information, Accounting Review 78, 275-296.

Rauh, J., 2006, Investment and financing constraints: Evidence from the funding of corporate pension plans, Journal of Finance 61, 33-71.

Stock, J., J. Wright, and M. Yogo, 2002, A Survey of weak instruments and weak identification in generalized method of moments, Journal of Business \& Economic Statistics 20, 518-529.

Stock, J., and M. Yogo, 2002, Testing for weak instruments in linear IV regression, Working Paper 284, National Bureau of Economic Research.

Verdi, R., 2006, Information environment and the cost of equity capital, Working Paper, Massachusetts Institute of Technology, MA 02142.

U.S. Department of Labor, 2021, Private pension plan bulletin historical tables and graphs 1975-2018, Employee Benefits Security Administration, U.S. Department of Labor, January 2021, Table E-10, page 13.

https://www.dol.gov/sites/dolgov/files/ebsa/researchers/statistics/retirement-bulletins/privatepension-plan-bulletin-historical-tables-and-graphs.pdf 